\title{
Arap Dilinde Emâlî Geleneği: İbnu'ş-Şecerî̀nin el-Emâlî Adlı Eseri Üzerine Bir İnceleme*
}

\section{Hüseyin ERSÖNMEZ}

\begin{abstract}
Öz: Bu çalı̧̧mamızda Arap dili alanında yazılmış en önemli emâlî türü eserlerden olan İbnu'ş-Şecerînnin el-Emâlî adlı eseri ele alınmıștır. Yazdırmak, dikte ettirmek anlamlarına gelen imlâ kelimesinin çoğulu olan emâlî genel olarak şu şekilde tarif edilebilir: "Bir âlimin belli günlerde başta hadis olmak üzere Arap dili, tefsir, fikıh ve diğer ilimlerle ilgili bilgilerini ders halkasındaki oğrencilerine yazdırmasıyla ortaya çıkan bir eser türüdür." Muhaddislerden sonra en çok emâlî türü eser ortaya koyanlar Arap dili âlimleridir. Bu âlimler eserlerinde lugat ve nahiv konularını esas almakla birlikte imlâ esnasında kimi zaman ayetlerin tefsirine, hadislerin şerhine ve meşhur şairlerin şiirlerine de yer vermişlerdir. Bu anlamda İbnu'ş-Şecerî de el-Emâlî'sinde başta sarf, nahiv ve belâgat olmak üzere Arap dilinin bütün alanlarına değinmiştir. Çalışmamızda ilk olarak el-Emâlî’nin genel özellikleri, imlâ süreci, müellifin eserdeki metodu ve eserde işlenen konular ele alınmıştır. Daha sonra eserin kaynakları, eserden istifade edenler ve bu eser üzerine yapılmış çalışmalar tespit edilmeye çalş̧lımıştır.
\end{abstract}

Anahtar Kelimeler: Emâlî, Meclis, İbnu'ş-Şecerî, Arap Dili.

\section{Amālī Tradition in Arabic Language: A Study on Ibn al-Shajarīs al-Amālī}

\begin{abstract}
This study deals with al-Amālī of Ibn al-Shajarī which is one of the most important examples of them. Amālī, which is plural of imlā that means dictation, is a kind of book which is written by the author's students. It includes information about (mostly) hadith, Arabic language, interpretation of Qur'an, Islamic law and other religious sciences. In perspective of number, the second most written Amālī works are belongs to Arabic scholars after hadith scholars. The Arabic scholars mostly mentions about lexicology, grammar and in addition these two topics interpretations of ayahs, explanations of hadiths, wise words and poems of Arabic philosophers, poets and preachers. In this sense, al-Amālī of Ibn al- Shajarī mentions every aspects of Arabic language mainly notably morphology, syntax, rhetoric. At first in the study, features, process of writing, method, and topics of Amālī have been discussed. Besides, sources, effects of the book, and other research about it have been examined.
\end{abstract}

Keywords: Amālī, Majālis, Ibn al-Shajarī, Arabic Language.

* Bu makale, “İbnu'ş-Şecerî ve el-Emâlî Adlı Eserinin Belâgat Açısından İncelenmesi” başlıklı doktora tezimizden türetilmiştir. (İzmir Kâtip Çelebi Üniversitesi, Sosyal Bilimler Enstitüsü, 2020).

** Arş. Gör. Dr. İzmir Kâtip Çelebi Üniversitesi, İslami İlimler Fakültesi, Temel İslam Bilimleri Bölümü, Arap Dili ve Belâgatı Anabilim Dalı. E-Posta: huseyin.ersonmez@ikc.edu.tr ORCID ID: https://orcid. org/0000-0002-7875-9960. 


\section{Giriş}

\section{Emâlî Kavramı}

\subsection{Lugat Anlamı}

Emâlî (أماءع) veya umliye (أملاء) kelimesinin çoğuludur. İmlânın sözlükte "uzatmak, mühlet vermek, yazdırmak, dikte etmek"1 gibi manaları vardır. İmlâ kelimesinin aslının imlâl (إملإل) olduğu, imlâyı BenîTemîm'in, imlâli de Benî Esed'in kullandığı ifade edilmiştir. ${ }^{2}$ Bununla birlikte kelimenin her iki şekli de "yazdırmak" manasında Kurân-ı Kerîm'de yer almaktadır.

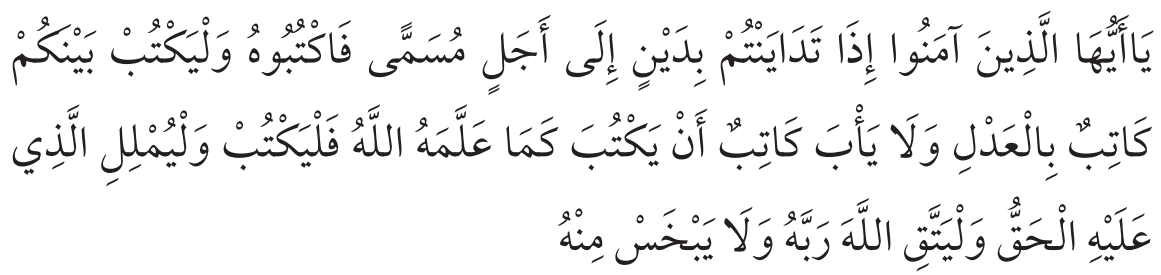

"Ey iman edenler! Belli bir süre için birbirinize borçlandığınız zaman bunu yazın. Aranızda bir yazıcı adaletle yazsın. Yazıcı, Allah'ın kendisine öğrettiği şekilde yazmaktan kaçınmasın, (her şeyi olduğu gibi dosdoğru) yazsın. Üzerinde hak olan (borçlu) da yazdırsın ve Rabbi olan Allah'tan korkup sakınsın da borçtan hiçbir şeyi eksik etmesin (hepsini tam yazdirsın)."14

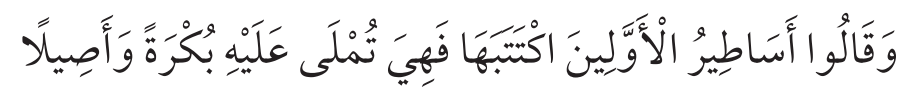

"Yazıp durduğu şey evvelkilerin masallarıdır; gece gündüz kendisine dikte edilmektedir, dediler." ${ }^{15}$

Görüldüğü üzere birinci ayette Benî Esed'in kullandığı أََّْْ kelimesi, ikinci ayette ise BenîTemîm'in kullandığı أَ أَمْلَ kelimesi benzer anlamlarda kullanılmıştır.

1 Halîl b. Ahmed el-Ferâhîdî, Kitâbu'l-'Ayn, (Mektebetu'l-Hilâl, tsz.), VIII, 344; İsmâil b. Hammâd el-Cevherî, Tâcu'l-lugâ ve Sıhâhu'l-arabiyye, (Beyrut: 1990), VI, 2498; Ebu'l-Fadl Cemâluddîn b. Manzûr, Lisânu'l-Arab, (Beyrut: 1993), XV, 290.

2 Ebû Abdillâh Muhammed b. Alî b. Muhammed eş-Şevkânî, Fethu'l-Kadîr, (Beyrut: 1993), I, 344.

3 Abdullah Aydınlı, "İmlâ", TDV İslâm Ansiklopedisi, (İstanbul: TDV Yayınları, 2000), XXII, 225-226.

4 el-Bakara 2/282.

5 el-Furkan 25/5. 


\subsection{Terim Anlamı}

Terim olarak imlâ, "bir kimsenin etrafındakilere ezberinden veya kitaptan bir şey yazdırması" manasında kullanılmaktadır. Emâlîye ise Kâtip Çelebî (ö. 1657/1067) Keşfu'z-Zunûn'da şöyle bir tarif yapmıştır: "Emâlî imlâ kelimesinin çoğuludur. O da bir âlimin (ders halkasına) oturması, etrafındaki talebeler ise kalem ve defterleriyle oturup, âlimin söylediği bilgileri yazmasıdır. Zamanla bu yazılanlar kitap halini alır ve buna imlâ veya emâlî denir. Şâfii âlimler bunu ta'lîk olarak isimlendirirler." ${ }^{6}$

Bu anlamda yazılan esere imlâ veya emâlî denilmektedir. Talebeye yazdıran hocaya mümlî, hocanın söylediklerini yazan talebeye müstemlî veya bazen kâtib adı verilmektedir. Imlâ ile ilgili olarak kullanılan istimlâ da imlâ meclisinde hocanın yazdırdıklarını yazmak veya hocanın bu yazdırdıklarını uzaktakilere nakletmek anlamını ifade eder. Meclisin kalabalık olması halinde hocanın söylediklerini yüksek sesle uzaktakilere nakledenlere ise müstemlî veya mübelliğ denilmiştir.?

es-Suyûtî (ö. 911/1505) el-Muzhir adlı eserinde imlânın hadis hafızlarının en önemli vazifesi olduğunu söyledikten sonra dil ile ilgili emâlîleri şu şekilde tarif eder: "Dil ile alakalı emâlîlerin metodu hadis emâlîlerinin metoduyla aynıdır. Müstemlî öncelikle dersin başına dersin yapıldığı meclisi, hocasını, nerede, hangi tarih ve günde yapıldığını yazar. Daha sonra mümlî Arap kelamından sözleri isnadıyla birlikte zikreder. Içerisinde açıklanması gereken yerleri açıklar. Arap şiirlerinden senetleriyle aktarma yapar, dille ilgili faydalı gördüğü bilgileri ise ister senediyle isterse senetsiz olarak zikreder."

el-Kettânî (ö. 1927) ise emâlîyi şöyle açıklamıştır: "Emâlî imlânın çoğuludur. Eskiden âlimlerin, özellikle de ehli hadis hafızlarının en önemli görevlerindendi. Salı ve cuma günleri mescitte toplanılarak yapılırdı. Müstemlî (dersi yazan öğrenci) imlầ sının baş kısmına imlâ yaptığı meclisi, hocasını, gününü ve tarihini yazardı. Mümlî (dersi yazdiran hoca) hadisleri senetleriyle zikreder daha sonra garip kelimeleri açıklardı. Konuya ek olarak söylemek istediklerini de aktarırdı."9 Imlâ daha çok hadis ilminde başvurulan bir metot olmasından dolayı yapılan tanımlar da bu ilmin etrafında şekillenmiştir.

6 Kâtip Çelebî, Keşfu'z-Zunûn, (Bağdat: yy, 1941), I, 160.

7 Aydınlı, "İmlâ", XXII, 225.

8 Celâluddîn es-Suyûtî, el-Muzhir fî ulûmi'l-lugati ve envâ'ihâ, (Beyrut: 1998), Il, 269.

9 Muhammed b. Ca'fer el-Kettânî, er-Risâletü'l-müstetrafe, (Beyrut: 1986), 160. 
Bu bilgiler doğrultusunda emâlî kavramına şöyle bir tanım yapabiliriz: Emâlî,"Bir âlimin belli günlerde başta hadis olmak üzere, Arap dili, tefsir, fıkıh ve diğer ilimlerle ilgili bilgilerini ders halkasındaki öğrencilerine yazdırmasıyla ortaya çıkan bir eser türüdür."

\section{Emâlî Alanında Yazılan Eserler}

Emâlî türü eserler başta hadis olmak üzere, Arap dili, fıkıh, akâid ve tefsir alanlarında ortaya konmuştur. İlk olarak emâlîyi kimin telif ettiği kesin bir şekilde belli olmamakla birlikte bilinen en eski emâlîler Leys b. Sa'd'ın (ö. 791/175) Meclis min fevâid, İmam Ebû Yûsuf'un (ö. 182/798) el-Emâlî, Muhammed b. Hasan eş-Şeybânî'nin (ö. 189/805) Cüz' mine'l-Emâlî ve Ahmed b. Habîb eş-Şucâî'nin 184/800 yılında yazdığı Cüz' mine'l-Emâlî adlı eserleridir. Abdurrezzâk es-San'ânî'nin (ö 211/826-27) el-Emâlî fî Âsâri's-Sahâbe'si de ilk emâlîlerden sayılabilir. ${ }^{10}$

Hadis âlimlerinden sonra emâlî türünde en çok eser ortaya koyanların Arap dili ve edebiyatı, özellikle de lugat âlimleri olduğu anlaşılmaktadır. Bu âlimler eserlerinde nahiv ve lugat konularını esas almakla birlikte imlâ esnasında belli bir konuya bağlı kalmamışlardır. Ayetlerin tefsirine, hadislerin şerhine, meşhur şairlerin hikmetli söz ve şiirlerine de yer vermişlerdir. Ayrıca öğrencilerin çeşitli sorularını cevaplandırmaları, yazdırdıkları hususları şerh etmeleri bu meclislere olan ilgiyi daha da arttırmıştır. ${ }^{11}$

Arap edebiyatında Ebû Ubeyde Ma'mer b. el-Musennâ (ö. 210/825), İbnu'l-Arabî (ö. 219/834), Süleymân b. Muhammed el-Hâmid (ö. 305/918), el-Ahfeş (ö. 316/928), Niftaveyh (ö. 323/935), Cahza el-Bermekî (ö. 324/936), Ebû Bekr es-Sûlî (ö. 335/946), İbn Hâleveyh (ö. 370/980), İbn Fâris (ö. 395/1005) gibi önemli dilciler tarafından Kitâbu'l-Emâlî adı altında eserler telif edilmiş olmakla birlikte bu eserler günümüze ulaşmamıştır. ${ }^{12}$

Günümüze ulaşan eserlerden Sâlleb'in (ö. 291/904) el-Mecâlis'i, Ebû Abdillâh Muhammed b. Abbâs el-Yezîdî (ö. 313/925), İbn Dureyd (ö. 321/933), ez-Zeccâcî (ö. 337/949), Ebû Ali el-Kâlî (ö. 356/967), eş-Şerîf el-Murtazâ (ö. 436/1044), İbnu'ş-Şecerî (ö. 542/1148) ve İbnu'l-Hâcib'in (ö. 646/1249) el-Emâli’si alanın en meşhur eserlerindendir. ${ }^{13}$

Bu anlamda Arap dili alanında yazılmış emâlîler arasında önemli bir yer tutan İbnu'ş-Şecerî'nin el-Emâlî́si üzerinde durmak istiyoruz. 


\section{3. İbnu'ş-Şecerî'nin el-Emâlî'si}

el-Emâlî Seyyid Zeynelâbidîn el-Mûsevî, Habîb Abdullah b. Ahmed el-Alevî ve Abdurrahman el-Yemânî́nin birlikte yaptıkları tashihle Haydarâbâd'da 1349/1930 yılında iki cilt halinde basılmıştır. Bu baskı, eserin Âsafiye Kütüphanesi'nde bulunan birinci cildiyle Freitz Krenkow vasıtasıyla elde edilen İstanbul kütüphanelerindeki nüshalarına dayanmaktadır. Faydalanılan İstanbul nüshasının ise yeri ve numarası belirtilmemiştir. ${ }^{14}$

Beyrut'ta ofset baskıları da yapılan bu neşir eksiktir. Hâtim Sâlih ed-Dâmin tarafından yetmiş sekizinci meclisin bir kısmını ve son altı meclisi ihtiva eden kısım

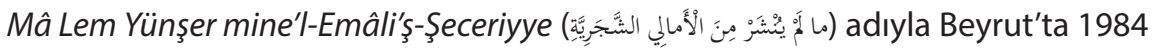
yılıda yayımlamıştır. ed-Dâmin eserinin mukaddimesinde esas aldığı nüshalarla ilgili bilgiler de vermiştir. ${ }^{15}$ Bu nüshalar;

- Bağdat Yüksek Öğretim Kütüphanesi'nde 369 numarada bulunan ve h. 614 yılından yazılmış bir nüsha. Bu nüshada elli altıncı meclisten eserin sonuna kadar olan kısmı vardır.

- Teymûriyye Kütüphanesi'nde 672 numarada bulunan 1920 yılında yazılmış bir nüsha.

Mahmûd Muhammed et-Tanâhî ise eserin birçok nüshasından bahsetmekle birlikte Râgıb Paşa Kütüphanesi'ndeki (Edeb-59) nüshayı esas alıp Âsafiye Kütüphanesi'ndeki (Belâgat-70) nüshadan da yararlandığını belirtmiş ${ }^{16}$ ve müellif hakkında geniş bir mukaddime ilâve ederek kitabın tamamını Kâhire'de 1413/1992 yılında üç cilt halinde neşretmiştir. ${ }^{17}$

\section{Eserin el-Emâlî Olarak Adlandırılması ve İbnu'ş-Şecerî'ye Aidiyeti}

İbnu'ş-Şecerî eserinin farklı yerlerinde bu kitabını el-Emâlî olarak isimlendirmiştir. Eserde yaklaşık on sekiz yerde İbnu'ş-Şecerî kitabından el-Emâlî olarak bahsetmektedir. ${ }^{18}$ Örneğin, müellif eserinde "el-Emâlî'de bunu daha önce zikrettik", "elEmâlî'de daha önce bunu şerh ettim", "bu konuda el-Emâlî'de daha önce yeterli bilgi

15 Hâtim Sâlih ed-Dâmin, Mâ lem yünşer mine'l-Emâli'ş-Şeceriyye, (Beyrut: Müessesetü'r-Risâle, 1984), 7.

16 İbnu'ş-Şecerî, el-Emâlî, (Kâhire, yy, 2014), (muh. mukaddimesi), l, 205, 206, 207.

17 Elmalı, "el-Emâlî", XI, 73; Ayrıca bkz. Demirayak, Arap-Islam Edebiyatı Literatür Bilgisi, 45-46.

18 İbnu'ş-Şecerî, el-Emâlî, I, 126, 169, 233, 243, 256, 273, 384, 433; II, 18, 32, 84, 237, 454, 460, 585, $601 ;$ III, 133, 209. 
verdim", "bu beytin irâbını el-Emâlî́de daha önce verdik ancak burada bir problemi gidermek için ve daha faydalı olduğunu düşündüğümüzden tekrar ediyoruz" gibi ifadeler kullanmıştır. Dolayısıyla buradan hareketle eserin el-Emâlî olarak isimlendirilmesinde herhangi bir ihtilafın olmadığını söyleyebiliriz.

Eserin İbnu'ş-Şecerî'ye aidiyetine gelince, müelliften bahseden tabakât kitaplarının tamamı onun el-Emâlî adlı bir eserinin olduğunu zikretmişlerdir. ${ }^{19}$ Ayrıca eserin İbnu'ş-Şecerî'ye aidiyeti ile ilgili herhangi bir görüş ayrılığının olmadığını da görmekteyiz.

\section{Eserin İmlâ Süreci}

Seksen dört meclisten oluşan İbnu'ş-Şecerî'nin el-Emâlî́sinin bir diğer özelliği ise bazı meclislerin başında o meclisin ne zaman yapıldığının tarihinin yazılmasıdır. Bu tarihler İbnu'ş-Şecerî tarafından mı yazdırıldı yoksa eseri imlâ eden talebeleri tarafından daha sonra mı yazıldı, bununla ilgili kesin bir bilgi elimizde bulunmamaktadır. Eserde ilk olarak sekizinci meclisin tarihi, son olarak ise otuz üçüncü meclisin tarihi belirtilmiştir. Tarih kaydı düşülen meclisler ve tarihleri şu şekildedir:

- Sekizinci meclis: h. 524 yılı Cemâziyelevvel'in ilk Cumartesi günü. ${ }^{20}$

- Dokuzuncu meclis: 8 Cemâziyelevvel h. 524 Cumartesi. ${ }^{21}$

- Onuncu meclis: 22 Cemâziyelevvel h. 524 Cumartesi. ${ }^{22}$

- On birinci meclis: h. 524 yılı Cemâziyelevvel'in son Cumartesi günü. ${ }^{23}$

- On üçüncü meclis: 4 Cemâziyelâhir h. 524 Cumartesi. ${ }^{24}$

- On beşinci meclis: 28 Cemâziyelâhir h. 524 Cumartesi. ${ }^{25}$

- On altıncı meclis: 6 Recep h. 524 Cumartesi. ${ }^{26}$

- On yedinci meclis: 13 Recep h. 524 Cumartesi. ${ }^{27}$

Örnek için bkz. İbnu'l-Enbârî, Nüzhetu'l-Elibbâ, (Ürdün: yy, 1985), 300; Yâkût el-Hamevî, Mu'cemu'l-udebâ, (Beyrut: yy, 1993), VI, 2775; el-Kıftî, İnbâhu'r-ruvât, (Beyrut: yy, 1982), III, 356.

İbnu'ş-Şecerî, el-Emâlî, l, 71.

İbnu'ş-Şecerî, el-Emâlî, l, 83.

İbnu'ş-Şecerî, el-Emâlî, I, 95.

İbnu'ş-Şecerî, el-Emâlî, I, 104.

İbnu'ş-Şecerî, el-Emâlî, I, 126.

İbnu'ş-Şecerî, el-Emâlî, I, 148.

İbnu'ş-Şecerî, el-Emâlî, I, 157.

İbnu'ş-Şecerî, el-Emâlî, I, 166. 
- On sekizinci meclis: 20 Recep h. 524 Cumartesi. ${ }^{28}$

- On dokuzuncu meclis: 27 Recep h. 524 Cumartesi. ${ }^{29}$

- Yirminci meclis: 4 Şaban h. 524 Cumartesi. ${ }^{30}$

- Yirmi birinci meclis: 13 Şaban h. 524 Cumartesi. ${ }^{31}$

- Yirmi ikinci meclis: 23 Cemâziyelevvel h. 526 Salı. ${ }^{32}$

- Yirmi üçüncü meclis: h. 526 yılı Cemâziyelevvel'in son Salı günü. ${ }^{33}$

- Yirmi dördüncü meclis: 8 Cemâziyelâhir h. 526 Salı. ${ }^{34}$

- Yirmi beşinci meclis: h. 526 Cemâziyelâhir ayının ortasındaki Salı günü. ${ }^{35}$

- Yirmi altıncı meclis: h. 526 Cemâziyelâhir ayının son Salı günü. ${ }^{36}$

- Yirmi yedinci meclis: 7 Recep h. 526 Salı. $^{37}$

- Yirmi sekizinci meclis: 26 Şaban h. 526 Salı. ${ }^{38}$

- Yirmi dokuzuncu meclis: 9 Şevvâl h. 526 Salı. ${ }^{39}$

- Otuzuncu meclis: 16 Şevvâl h. 526 Salı. ${ }^{40}$

- Otuz birinci meclis: 23 Şevvâl h. 526 Salı. ${ }^{41}$

- Otuz ikinci meclis: 8 Rebîulevvel h. 536 Cumartesi. ${ }^{42}$

- Otuz üçüncü meclis: 15 Rebîulevvel h. 536 Cumartesi. ${ }^{43}$

Yukarıda da görüldüğü üzere sekizinci meclisten başlayarak otuz üçüncü meclise kadar tarihler belirtilmiştir. Ancak arada on ikinci ve on dördüncü meclislerin tarihleri belirtilmemiştir. Verilen tarihlerden on üçüncü ve on beşinci meclislerin tarihlerinden birisinin ise yanlış olarak kayda geçildiğini görmekteyiz. Zira aynı

\footnotetext{
28 İbnu'ş-Şecerî, el-Emâlî, I, 176.

29 İbnu'ş-Şecerî, el-Emâlî, I, 187.

30 İbnu'ş-Şecerî, el-Emâlî, I, 198.

31 İbnu'ş-Şecerî, el-Emâlî, I, 207.

32 İbnu'ş-Şecerî, el-Emâlî, I, 216.

33 İbnu'ş-Şecerî, el-Emâlî, I, 228.

34 İbnu'ş-Şecerî, el-Emâlî, I, 238.

35 İbnu'ş-Şecerî, el-Emâlî, I, 248.

36 İbnu'ş-Şecerî, el-Emâlî, I, 259.

37 İbnu'ş-Şecerî, el-Emâlî, I, 270.

38 İbnu'ş-Şecerî, el-Emâlî, I, 280.

39 İbnu'ş-Şecerî, el-Emâlî, I, 293.

40 İbnu'ş-Şecerî, el-Emâlî, I, 304.

41 İbnu'ş-Şecerî, el-Emâlî, I, 314.

42 İbnu'ş-Şecerî, el-Emâlî, I, 368.

43 İbnu'ş-Şecerî, el-Emâlî, I, 383.
} 
ayın 4'ü ile 28'inin aynı gün (cumartesi) olması mümkün görünmemektedir. On üçüncü ve on beşinci meclislerin öncesine ve sonrasına baktığımız zaman, on üçüncü meclisin tarihinin 14 Cemâziyelâhir yerine 4 Cemâziyelâhir olarak yanlış kaydedildiğini söyleyebiliriz. Bu anlamda tarihleri belirtilmeyen on ikinci meclisin 7 Cemâziyelâhir h. 524 Cumartesi, on dördüncü meclisin ise 21 Cemâziyelâhir h. 524 Cumartesi günü yapıldığı kanaatindeyiz.

Ayrıca yirmi birinci ve yirmi ikinci meclislerin arasında iki yıllık, otuz birinci ve otuz ikinci meclislerin arasında ise on yıllık bir ara verildiğini görmekteyiz. İbnu'ş-Şecerî başlangıçta meclislerini cumartesi günleri düzenlerken iki yıllık aranın ardından meclisleri salı günü yapmaya başlamıştır. Otuz birinci meclisten sonra vermiş olduğu on yıllık aranın ardından ise meclisleri tekrar cumartesiye almıştır.

Bunun dışında otuz birinci meclis ile otuz ikinci meclis arasında müellifin meclislerinden olmadığı ancak önemine binaen oraya h. 539 yılı Rebîulâhir ayında eklendiğine dair bir not bulunan bazı konular vardır. ${ }^{44}$ Meclisin sonuna bu şekilde yapılan bir eklemenin, eserdeki tarihlerin de daha sonradan müellifin eseri imlâ eden talebeleri tarafından eklenmiş olabileceğini göstermektedir.

Genel olarak diyebiliriz ki, eserdeki tarih kayıtlarına baktığımız zaman -h. 539 yılına dair tarih kaydının daha sonradan eklendiğini düşünürsek- ilk otuz üç meclisin h. 524-536 yılları arasında imlâ edildiğini söylemek mümkündür. Ayrıca son tarih kaydı otuz üçüncü mecliste olup seksen dördüncü meclise kadar olan kısmın tamamlanmasının müellifin hayatının son anlarına kadar devam ettirilmiş olma olasılığı yüksektir.

\section{6. İbnu'ş-Şecerî'nin Eserdeki Metodu}

Ibnu'ş-Şecerî meclislerin başında genellikle o meclisi hangi konuya ayıracaksa onu belirtir. Meclislere sarf-nahiv meseleleri, bazı ayetlerin tefsiri, ${ }^{45}$ bazı şiirlerin irâb ve mana açısından tahlili ${ }^{46}$ ile başlar. Kimi zaman ise kendisine sorulan soruları cevaplar.

Eserde işlenen konuları üç grupta ele almak mümkündür. Birincisi müellifin bizzat kendisinin ortaya attığı meseleler, ikincisi müellifin talebeleri tarafından 
sorulan sorulara verilen cevaplar, üçüncüsü ise başka şehirlerden gelerek İbnu'ş-Şecerî'ye sorulan sorulara verdiği cevaplar. ${ }^{47}$

İbnu'ş-Şecerî konuları işlerken tekrardan kaçınmaya çalışır, ancak bazen önemine

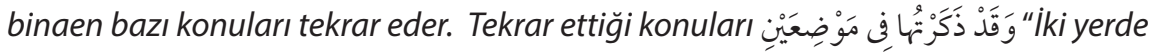

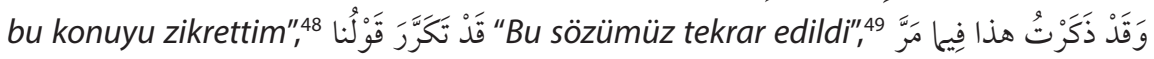

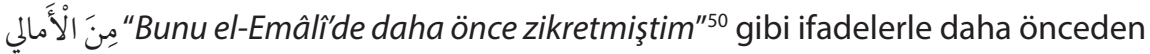
değindiğine işaret eder. Yine eserinde daha önceden detaylı olarak değindiği

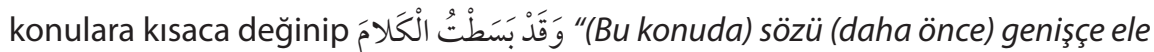

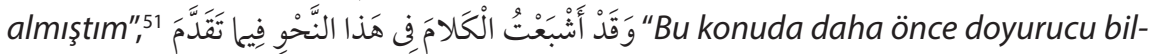
gi vermiştim" ${ }^{\prime 2}$ gibi ifadelerle önceki yerlere işaret eder. Örneğin, İbnu'ş-Şecerî muzafun ileyhten hâl gelmesi, ${ }^{53}$ muzâfın hazfedilip muzâfun ileyhin onun yerini alması, fiillerin birbiri yerine kullanılması ${ }^{54}$ gibi konuları tekrar etmiştir. Bununla birlikte müellif tekrar ettiği bir konuda öncekinden farklı bir görüş zikretmiştir. Şöyle ki, ما وَدَّعَكَ رَبُّكَ وَما قَلى "Rabbin seni terketmedi ve darılmadı" "darılmadı" ifadesi için eserinin bir yerinde muhâtaptan gâibe bir iltifât sanatının olduğunu söylerken, ${ }^{56}$ başka bir yerinde ise ifadedeki mefûlun hazfedilmiş olduğunu ve takdîrinin وما قلاكك "sana darılmadı" olduğunu söyler.

Müellif eserinde ele aldığı konularla ilgili daha önceki dilcilerin görüşlerinden bahseder. Bu görüşlerle alakalı olarak çoğu yerde kendi düşüncesini de söyler. Kimi zaman önceki dilcileri eleştirir kimi zaman ise görüşün doğruluğunu ortaya koyar. Bu anlamda doğru bulduğu görüşleri الصَّحِيحُ عِنْدي "doğru olan..."الصَّحِيح

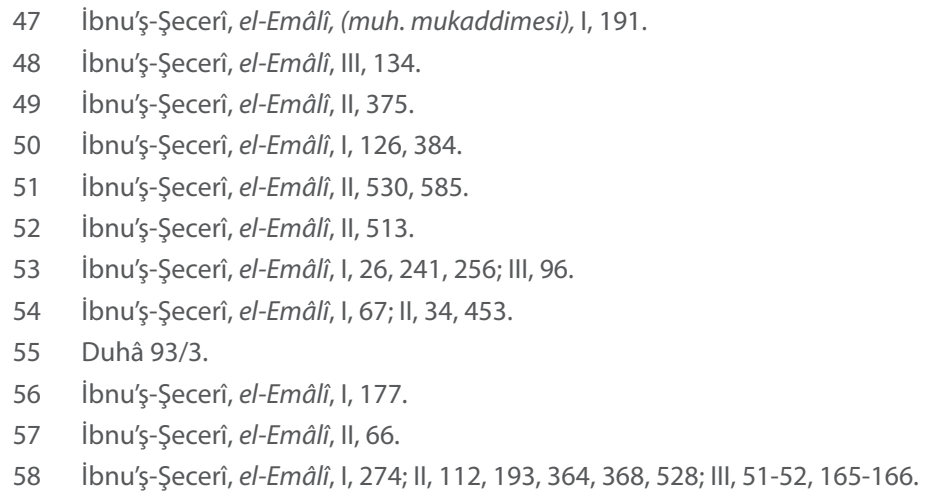




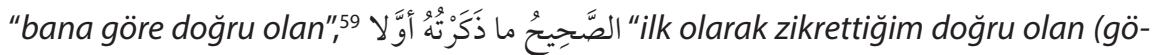

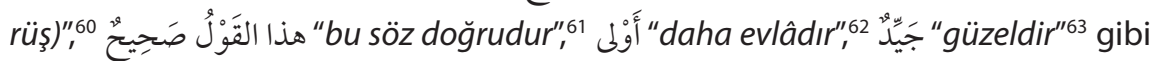
ifadelerle belirtir.

Bunun yanı sıra katılmadığı ve doğru bulmadığı görüşlerle ilgili ise şu ifadele-

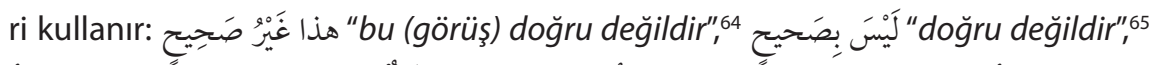

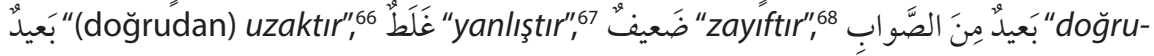

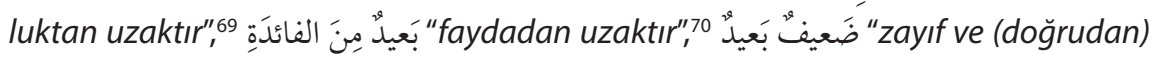
uzaktır"171

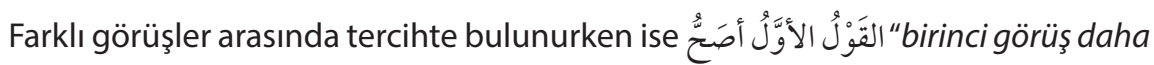

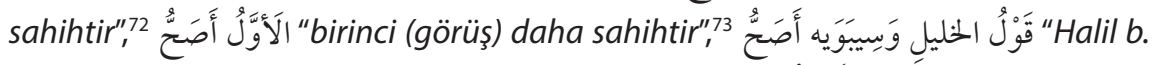

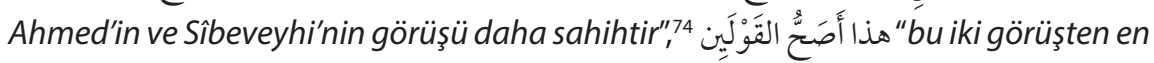
sahih olanıdır"75 gibi ifadeler kullanmıştır.

Ibnu'ş-Şecerî́nin eserinde takip ettiği metotlarından birisi de muhtemel sorulara cevap vermesidir. Bu metot klasik kitapların çoğunda karşımıza çıkan bir üslup-

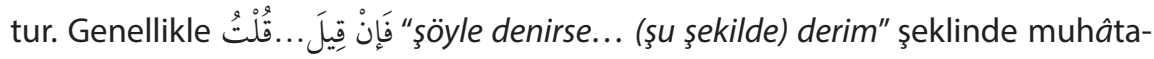
bın sorabileceği soru üzerinden mesele açıklanır. Müellif de eserinin birçok yerinde meseleleri bu şekilde açıklar. Bu anlamda İbnu'ş-Şecerî daha çok .... فَإِنْ قِيًَ

İbnu'ş-Şecerî, el-Emâlî, I, 349, 363.

İbnu'ş-Şecerî, el-Emâlî, I, 375.

İbnu'ş-Şecerî, el-Emâlî, II, 282.

İbnu'ş-Şecerî, el-Emâlî, I, 64, 110, 254, 315, 318, 320; II, 73, 526.

İbnu'ş-Şecerî, el-Emâlî, I, 72, 182; II, 452, 538; III, 100.

ibnu'ş-Şecerî, el-Emâlî, I, 414; II, 257, 394, 415; III, 187, 189, 269.

İbnu'ş-Şecerî, el-Emâlî, I, 416; III, 16, 129, 167.

İbnu'ş-Şecerî, el-Emâlî, I, 284, 386; II, 103; III, 100.

Aynı kelimenin fiil halleriyle kullanımı da vardır. Örnekler için bkz. Ibnu'ş-Şecerî, el-Emâlî, II, 258, 451, 517; III, 29, 177, 179-180, 273.

İbnu'ş-Şecerî, el-Emâlî, II, 72, 82, 118.

İbnu'ş-Şecerî, el-Emâlî, II, 442.

İbnu'ş-Şecerî, el-Emâlî, I, 254, 311.

İbnu'ş-Şecerî, el-Emâlî, III, 147.

İbnu'ş-Şecerî, el-Emâlî, l, 209.

İbnu'ş-Şecerî, el-Emâlî, l, 398.

İbnu'ş-Şecerî, el-Emâlî, II, 553.

İbnu'ş-Şecerî, el-Emâlî, III, 151. 


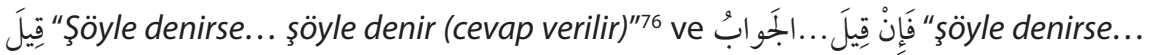

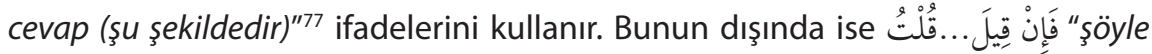

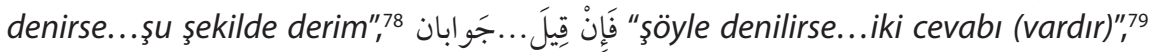

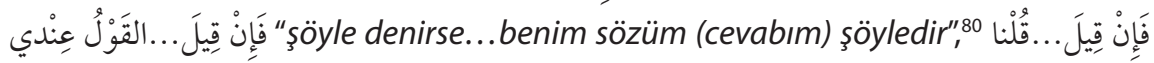
"şöyle denirse... deriz ki"si gibi ifadeler de kullanmıştır.

Müellifin eserde takip ettiği metotlardan birisi de anlattığı konuları ayet, hadis, şiir ve mesel örnekleriyle zenginleştirmesidir. İbnu'ş-Şecerînin bu özelliği hemen hemen bütün konularda kendini göstermektedir. Araştırmamızda özellikle belâgat, sarf ve nahiv ile ilgili müellifin görüşlerini açıklamaya çalıştığımız yerlerde onun bu yönüne işaret etmeye çalışacağız.

\section{Eserin Genel Özellikleri}

el-Emâlî İbnu'ş-Şecerî'nin en önemli ve en geniş eseridir. Daha önce de değindiğimiz gibi eserde Arap dilinin bütün alanlarıyla ilgili konulara yer verilmiştir. Müellif konuları işlerken dili olabildiğince akıcı kullanmaya çalışmı̧, verdiği çokça örneklerle de konunun daha iyi anlaşıımasını sağlamaya çalışmıştır. İbnu'ş-Şecerî'nin meşhur talebelerinden İbnu'l-Enbârî (ö. 577/1181) hocasının fasih, tatlı sözlü ve güzel bir anlatım üslubuna sahip olduğunu aktarır. ${ }^{82}$ İbn Hallikân da (ö. 681/1282) benzer şekilde müellifin güzel sözlü, fasih ve anlatımı çok iyi olan bir üsluba sahip olduğunu nakleder. ${ }^{83}$ İbnu'ş-Şecerî'nin bu özelliği eserinin hemen hemen her tarafına yansımıştır.

Müellif eserindeki kendi anlatım tarzını beğendiğini ve bununla övündüğünü de görmekteyiz. Örneğin, o bazı meseleleri izah ettikten sonra"Bu faslı iyi tefekkür et. Zira başka birisinin bu şekilde anlattığını bilmiyorum"84 veya "Bu faslı ezberle. Çünkü bu büyük bir asıldır"85 gibi ifadeler kullanmıştır.

İbnu'ş-Şecerî, el-Emâlî, I, 1, 49, 164, 235, 433; II, 94, 119, 138, 148, 157, 186, 195, 260, 333, 342, 343, 350, 439, 529; III, 25, 195.

İbnu'ş-Şecerî, el-Emâlî, I, 18, 113, 115, 237, 244, 251, 257, 268, 309, 331, 354; II, 8-9, 53, 155, 339, 350, 350, 491; III, 166, 210.

İbnu'ş-Şecerî, el-Emâlî, II, 364.

İbnu'ş-Şecerî, el-Emâlî, II, 375, 376; III, 206.

İbnu'ş-Şecerî, el-Emâlî, III, 98.

İbnu'ş-Şecerî, el-Emâlî, III, 105.

İbnu'l-Enbârî, Nüzhetu'l-elibbâ, 300.

İbn Hallikân, Vefayâtu'l-a'yân, (Beyrut: yy, 1994), VI, 46.

İbnu'ş-Şecerî, el-Emâlî, II, 117.

İbnu'ş-Şecerî, el-Emâlî, III, 194. 
el-Emâlî, çeşitli gramer konuları, meşhur Arap şairlerinin bazı şiirleri, lugat, belâgat, kafiye, arûz, bazı âyetlerin tefsirleri, tarih, ahbâr ve müellifin naklettiği şiirlerde geçen şehirlere dair bilgiler içermektedir. Bazen fasıl veya mesele başlıkları altında mevzû dışına çıkan İbnu'ş-Şecerî kimi zaman kendisine yöneltilen soruları veya muhtemel soruları cevaplandırmakta, kimi zaman ise tarihî ve edebî bilgilere de yer vermekte, meşhur dilcilerin konuyla ilgili görüşlerini aktarmakta, konunun sonunda ise kendi görüşünü ve tercihini belirtmektedir.

Eserde genel olarak sarf, nahiv ve belâgat konuları ele alınmakla birlikte, müellif hurûfu'l-meânî ve edatlara da önem vermiş, bazı meclisleri bu konulara ayırmıştır. ${ }^{86}$

Bazı meclis girişlerinde İbnu'ş-Şecerî'nin talebelerinden eseri imlâ edenlerce mü-

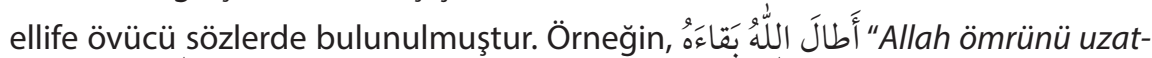
sın", "A7 "Allah düşmanlarını

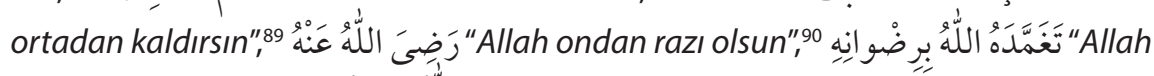

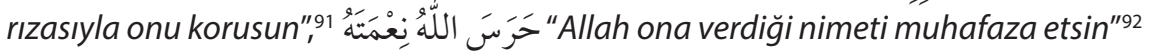

Bazı meclis girişlerinde o meclisin yapıldığı tarih ve gün yazılmıştır. Eserin imlâ süreci başlığı altında bu konuyu detaylı olarak incelemeye çalıştık. Genellikle salı ve cumartesi günleri yapılan meclisler ayet tefsiri, şiir irâbı ve tahlili, sarf-nahiv-belâgat konularının izahı gibi konularla başlar. Meclisin sonunda ise

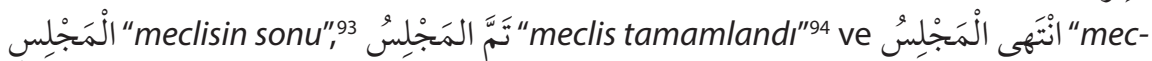
lis bitti"195 gibi ifadelerle o meclisin tamamlandığı belirtilir.

İbnu'ş-Şecerî eserinde bazı dilcileri sert bir dille eleştirmiştir. Bunlar arasında Meliki'nNuhât adıyla meşhur Ebû Nizâr'ı (ö. 568/1173), ${ }^{96}$ el-Emâlî̀ye reddiye yazan talebesi İbnu'l-Haşşâb'ı" ${ }^{97}$ ve Mekkî b. Ebî Tâlib'i sayabiliriz. ${ }^{98}$

Örnek için bkz. İbnu'ş-Şecerî, el-Emâlî, III, 39, 46, 62, 70.

İbnu'ş-Şecerî, el-Emâlî, I, 3.

İbnu'ş-Şecerî, el-Emâlî, I, 13.

İbnu'ş-Şecerî, el-Emâlî, I, 5, 23, 33, 62.

İbnu'ş-Şecerî, el-Emâlî, l, 3, 5, 13.

İbnu'ş-Şecerî, el-Emâlî, I, 5, 23.

İbnu'ş-Şecerî, el-Emâlî, I, 5.

İbnu'ş-Şecerî, el-Emâlî, I, 32, 70, 82, 103, 114, 156, 165, 186, 197, 215, 227, 247, 292, 303; II, 12; III, 142.

İbnu'ş-Şecerî, el-Emâlî, I, 322, 416, 435.

İbnu'ş-Şecerî, el-Emâlî, II, 204; 239.

İbnu'ş-Şecerî, el-Emâlî, II, 363-364.

İbnu'ş-Şecerî, el-Emâlî, III, 133.

İbnu'ş-Şecerî, el-Emâlî, III, 164; Ayrıca bkz. İbnu'ş-Şecerî, el-Emâlî, III, 163, 183. 
Müellif el-Emâlî́sinde İbn Debbâs'ın el-Mu'lem adlı eserine bir reddiye yazdığını da söylemiştir. ${ }^{99}$ Bu kitap İbnu'ş-Şecerî'nin el-Emâlî'sinde zikri geçen tek eseridir.

Eserin tahkikini yapan et-Tanâhî mukaddimede eserin önemine dair maddeler halinde bazı bilgiler paylaşmıştır. Bu bilgiler genel olarak şunlardır: ${ }^{100}$

- el-Emâlî Kurânî araştırma kitaplarından birisi sayılır. Öyle ki İbnu'ş-Şecerî eserinde bazı ayetlerin tefsirini, irâbını, ayetlerdeki hazfleri ve müşkilleri genişçe ele almıştır.

- Ibnu'ş-Şecerî Sibeveyhi'nin (ö. 180/796) ve Ebû Ali el-Fârisî́nin (ö. 377/987) şârihleri arasında sayılır. Müellif Sîbeveyhi'nin meşhur eseri el-Kîtâb'ın günümüzdeki baskılarında olmayan metinleri ve şevâhidi aktarmıştır.

- Müellif günümüze ulaşmayan bazı eserlerden de aktarımda bulunmuştur. Örneğin, Ebu'l-Hasan Ahfeş el-Evsat'ın (ö. 215/830) el-Evsat adlı eserini, Ebû Bekr İbnu'l-Enbârî́nin (ö. 328/940) el-Vâsit adlı eserini ve Ebû Ali el-Fârisînnin bazı kitaplarını bunlar arasında zikredebiliriz.

- el-Emâlî hazflerden, irâb meselelerinden, edatlar ve hurûfu'l-meânîden bahseden kitapların başında sayılır.

- Ibnu'ş-Şecerî eserinde basit ifadelerle, çokça örneklerle, zorluktan ve karmaşıklıktan uzak durarak nahvi öğretmeyi amaçlar.

- Eserin dil ilimlerinden delâlet ve iştikâk ilimlerinde de önemli bir yeri vardır.

- Eserde her dönemden şairlerin şiirleriyle istişhâdda bulunmuş bu konuda birçok dilciden farklı davranmıştır. İbnu'ş-Şecerî́nin şiirdeki istişhâd meselesine bakışını el-Emâlî́de istişhâd/şiir başlığı altında daha detaylı değineceğiz.

- Eserde el-Ahtal (ö. 92/710-11), Küseyyir (ö. 105/723), Ebû Duâd el-liyâdî (ö. 240/854), Ebû Hayye en-Numeyrî (ö. II/VIII. yüzyıl) gibi şairlerin divanlarının günümüz baskılarında mevcut olmayan şiirlerine de yer verilmiştir.

- Müellif el-Mütenebbî́nin (ö. 354/965) şârihlerinden birisi de sayılır. Zira el-Mütenebbî'ye ayırdığı ve onun faziletinden, hikmetlerinden ve şiirlerinden örneklere ayırdığı son meclis hariç, eserde seksen beş yerde el-Mütenebbî'den bahsetmiştir. 


\section{8. el-Emâlî'de İstişhâd}

Sözlükte şahit getirmek, şahit göstermek anlamlarına gelen istişhâd ${ }^{101}$ terim olarak ise "bir kelimenin veya bir ifadenin lafız, anlam ve kullanım doğruluğunu kanıtlamak amacıyla doğruluğu kesin olan nazım ve nesirden örnek vermek" anlamındadır. Bunun için getirilen örneğe şâhid denir. Bazı kaynaklarda istişhâd yerine ihticâc ve istidlâl ifadeleri de kullanılmıştır. ${ }^{102}$ Misal ile şâhid arasında bir fark vardır. Şöyle ki, misal şâhidden geneldir ve şâhid bir kuralın doğruluğunu kanıtlamak için getirilirken, misal o kuralı daha anlaşılır kılmak ve açıklamak için getirilir. ${ }^{103}$

Bu anlamda İbnu'ş-Şecerî bir meseleyi ele alırken sözlerini desteklemek için başta Kurân-ı Kerîm olmak üzere, hadis, şiir, mesel ve Arap kelâmından istişhâdda bulunmuştur.

\subsection{Kurân ve Kıraat}

Kurân-ı Kerîm en fasih ve beliğ söz olarak kabul edildiğinden istişhâdda kendisine başvurulan temel kitap olmuştur. İbnu'ş-Şecerî de eserinde başta nahiv olmak üzere, sarf, lugat ve belâgatla ilgili meseleleri açıklarken Kurân'la istişhâdı çok fazla kullanmıştır. Ayrıca İbnu'ş-Şecerî Kurân kıraatlerini şâz olsun mütevatir olsun nahiv, sarf, lugat ve belâgat meselelerinde istişhâd olarak kullanmıştır. Bu her iki durumun örneklerinin tamamını burada ele almak mümkün değildir. Fakat bir fikir vermesi açısından bazı misaller zikretmeyi yararlı görüyoruz. Örneğin, mü-

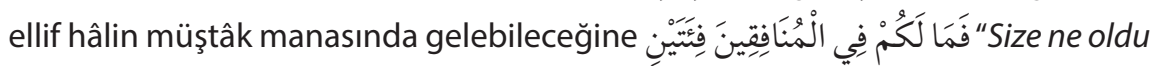
da münafıklar hakkında iki gruba ayrıldınız?"104 ayetini delil olarak getirmiştir. Ona göre, ayette فِ فِتَتيَنِ kelimesi müştâk manasında hâl olup مُخْتَفَفَنْنِ anlamındadır. ${ }^{105}$ İbnu'ş-Şeceri harfi cerlerin kimi zaman hazfedilebileceğini söylemiş ve bu duruma "Musâ kavminden yetmiş adam seçti"106 ayetini şâhid

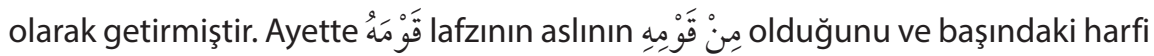
cerin hazfedildiğini ifade etmiştir. ${ }^{107}$

101 İbn Manzûr, Lisânu'l-Arab, III, 238-240; ez-Zebîdî, Tâcu'l-'arûs, (Yy: Dâru'l-Hidâye, tsz.), VIII, 253.

102 İsmail Durmuş, "İstişhad”, TDV İslâm Ansiklopedisi, (İstanbul: TDV Yayınları, 2001), XXIII, 396.

103 Muhammed A'lâ b. Alî b. Muhammed Hâmid et-Tehânevî, Keşşâfü ıstılâhâti'l-fünûn ve'l-ulûm, (Beyrut: Mektebetu'I-Lübnân, 1996), II, 1447.

104 en-Nisâ 4/88.

105 İbnu'ş-Şecerî, el-Emâlî, III, 7.

106 el-A'râf 7/155.

107 i̇bnu'ş-Şecerî, el-Emâlî, l, 285. 
Ibnu'ş-Şecerî harfinin أَ أَيْ anlamında gelebileceğini söylemiş, bunun da kendisinden önceki cümleyi tefsir edeceğini ifade etmiştir. Bu duruma Kurân'dan وَعَهْدْنا إِلى

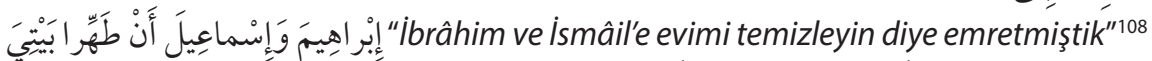

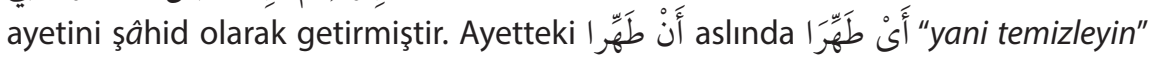
şeklinde olup, kendinden önceki durumu tefsir eder. Ayrıca İbnu'ş-Şecerî bu durumun bazı özel durumlarda ve tam bir cümleden sonra olabileceğini söyler. ${ }^{109}$

Ibnu'ş-Şecerî muhâtap emirlerde aslolanın J "lam" harfiyle kullanılması olduğunu fakat dile ağır geldiğinden bu harfin muhâtap emirlerde kullanılmadığını söyler. Bu duruma ise muhâtap emirde lam harfinin kullanıldığı Ubey kıraatindeki "Bununla sevinin"110 ayetini istişhâd olarak getirmiştir. ${ }^{111}$

\subsection{Hadis}

Kurân-ı Kerîm'den sonra ikinci temel kaynak olan hadislerle istişhâd meselesi tartışmalıdır. Bazı dilciler hadislerin mana ile rivayet olunduğundan onlarla istişhâdı caiz görmezken, ${ }^{112}$ bazı dilciler ise hadisleri dilsel meselelerde istişhâd olarak kullanmışlardır. ${ }^{113}$ İbnu'ş-Şecerî de eserinde Kurân ve şiirden daha az olmakla birlikte hadislerle istişhâdda bulunmuştur. Örneğin, hazf konusunu işlerken إٍِّ nin haberinin hazf edilebileceğine ve bunun da lafzı güzelleştireceğini söylemiş ve şu hadisi şâhid getirmiştir: ${ }^{114}$

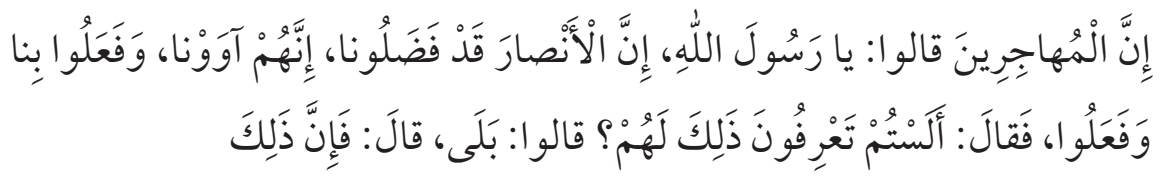

"Muhâcirler (Allah Rasûlüne) şöyle dediler: Ey Allah'ın Rasûlü, ensâr bize üstünlük sağladı. Bize sığınak oldular ve bize birçok iyilikler yaptılar. Allah Rasûlü ise şöyle dedi: Bunun onlar için ne anlama geldiğini bilmiyor musunuz? Onlar ise: Evet (bil-

108 el-Bakara 2/125.

109 İbnu'ş-Şecerî, el-Emâlî, III, 159.

110 Yunûs 10/58.

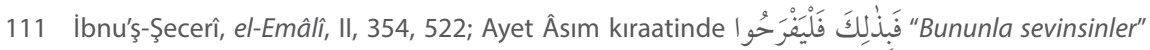
şeklinde gâib emir olarak gelir.

112 Durmuş, "İstişhad", 396.

113 Saîd el-Afgânî, fî Usûli'n-Nahv, (Beyrut: el-Mektebetu'l-İslâmî, 1987), 42.

114 İbnu'ş-Şecerî, el-Emâlî, II, 62-64. 
miyoruz) dediler. Allah Rasûlü de "işte budur" dedi."

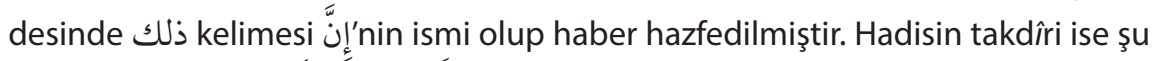

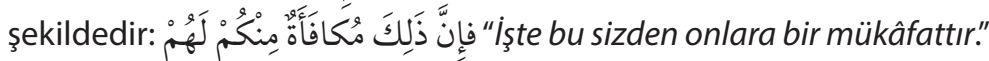

İbnu'ş-Şecerî haberin ${ }^{116}$ emir manasında gelebileceğini söylemiş ve şu hadisi şâhid olarak getirmiştir: ${ }^{117}$

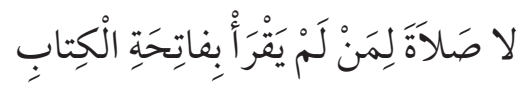

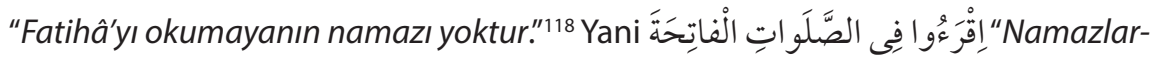
da Fâtihâ okuyun" anlamındadır.

Bir başka istişhâdda bulunduğu hadis ise emrin mendûb ve mubâh anlamına gelebileceği durumla ilgilidir. ${ }^{119}$

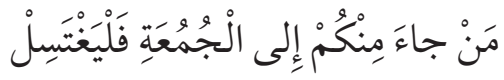

"Sizden kim Cuma'ya gelirse gusletsin."120 İbnu'ş-Şecerî'ye göre hadisteki "gusletsin" emri vucûbiyet değil, mendûb ve müstehâb bir mana ifade eder.

Son olarak Antere b. Şeddâd'ın (ö. 614) beyitlerini açıklarken hadisi istişhâd olarak kullandığı şu örneği vermek istiyoruz:

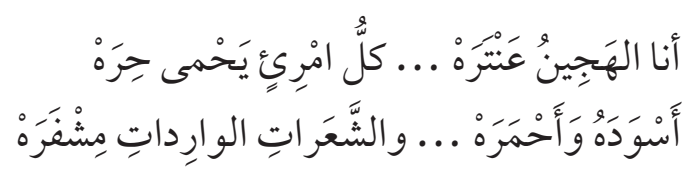

"Ben melez Antere'yim. Siyahı kırmızısı uzun saçlısı ve (sarkık) dudaklısı herkes namusunu (kadınını) korur." Müellif beyitteki الأسنوَد "siyah" lafzının Araplardan; "kırmızı" lafzının ise Arap olmayanlardan kinâye olduğunu söylemiş ve

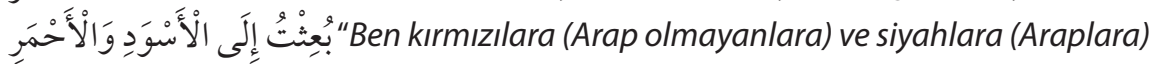
gönderildim"121 hádisini şâhid olarak getirmiştir. ${ }^{122}$

115 Ebû Ubeyd Kâsım b. Sellâm, Gârîbu'l-Hadîs, thk. Muhammed Abdulmuîd Hân, (Beyrut: Dâru'lKitâbi'l-Arâbî, 1396), II, 270-271.

116 Buradaki haber belâgattaki haber olup "kendisinde doğruluk veya yanlışlık bulunan söz" anlamındadır.

117 İbnu'ş-Şecerî, el-Emâlî, I, 394.

118 Buhâri, Kitâbu'l-Ezân, 756; Müslim, Kitâbu's-Salât, 34.

119 İbnu'ş-Şecerî, el-Emâlî, l, 411.

120 Buhârî, Kitâbu'l-Cumâ, 2; Müslim, Kitabu'l-Cumâ, 2.

121 Müslim, Kitâbu'l-Mesâcid, 3; Ahmed b. Hanbel, Müsned, III, 304; IV, 416; V, 145, 148.

122 İbnu'ş-Şecerî, el-Emâlî, II, 325. 


\subsection{Meseller ve Arap Kelâmı}

Sözlükte benzer, denk, örnek anlamlarına gelen mesel, ${ }^{123}$ Istılahta ise "açıklamak amacıyla benzeri hakkında söylenen söz" şeklinde tanımlanmıştır. ${ }^{124}$ Meselin kapsamlı olarak şu şekilde tarifi yapılabilir: "Kuvvetli tasvir içermesi, veciz olması ve kulağa hoş gelmesi gibi özelliklerinden dolayı, herkes tarafından kabul gören, nesilden nesile aktarılmasıyla meşhur olmuş, bir tecrübeye dayanan, dilden dile aktarılırken de lafzı değişmeyen, genellikle gerçek manası kastedilmeyip mecâzen başka şeylere delalet eden ve benzetme kastıyla söylenen kalıplaşmış ifadelerdir."125

Şehirli Araplar için hicri II. (VIII.) yüzyılın yarısına, bedevî Araplar için ise Câhiliye devrinden itibaren başlayan ve hicri IV. (X.) yüzyılın sonuna kadar uzanan dönem istişhâd dönemi olarak kabul edilmiş ve bu dönemlerde ortaya çıkan meseller kadîm meseller olarak nitelendirilmiştir. Bu dönemlerde Araplar diğer milletlerle karışmadığı ve dolayısıyla da dilleri bozulmadığı için onların meselleri ve şiirleri gramer kurallarını belirlemede şâhid olarak görülmüştür. ${ }^{126}$

Bu anlamda ibnu'ş-şecerî de mesellerle istişhâdı uygun görmüş ve eserinde me-

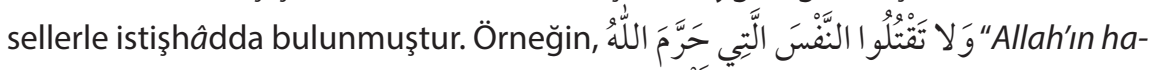
ram kıldığı kimseyi öldürmeyin"127 ayetindeki النَّنَّنَ

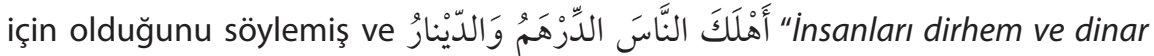

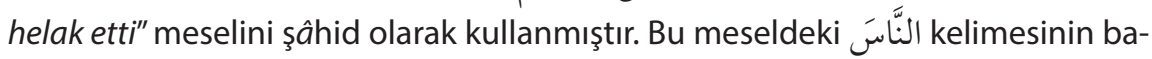
şındaki elif lam da ayetteki النَّنَّن kelimesindeki elif lam gibi cins ifade eder. ${ }^{128}$

M üenneslik ta'sının durumlarını ele aldığı yetmiş ikinci mecliste, müennes-

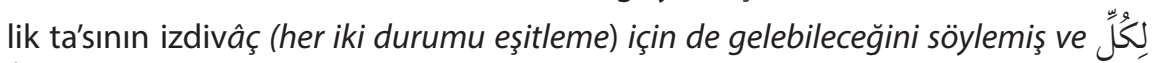
ساقِطَة لاقِطَة getirmiştir. Burada لاقِطِّar olarak gelmesi gereken kelime önceki kelimeye uyum

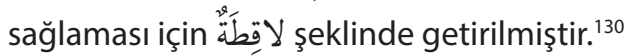

123 Ebu'l-Fadl Ahmed b. Muhammed b. Ahmed b. İbrâhîm el-Meydânî, Mecma 'u'l-emsâl, thk. Muhammed Muhyiddin Abdulhamîd, (Beyrut: Dâru'l-Mârife, tsz.), I, 1-6; Ebû Hilâl el-Askerî, Cemheratü'l-emsâl, (Beyrut: Dâru'l-Fikr,, tsz.), I, 7; İbn Manzûr, Lisânu'l-Arab, XI, 610.

124 er-Râgıb el-Isfahânî, el-Müfredât fî Garîbi'l-Kurân, thk. Safvân Adnân ed-Dâvûdî, (Dımeşk-Beyrut: Dâru'l-Kalem-Dâru'ş-Şâmiyye, 1412), I, 759. Yakup Kızılkaya, "Arap Dilinde Kâmin Meseller", (Doktora Tezi, Atatürk Üniversitesi, 2014), 10. İsmail Durmuş, “Mesel”, TDV İslâm Ansiklopedisi, (Ankara:TDV Yayınları, 2004), XXIX, 295. el-İsrâ 17/33. İbnu'ş-Şecerî, el-Emâlî, I, 75. el-Meydânî, Mecma 'u'l-emsâl, II, 193. İbnu'ş-Şecerî, el-Emâlî, III, 38. 
Zamirin mercii konusunu işlerken, zamirin merciinin kendisinden sonraki bir ke-

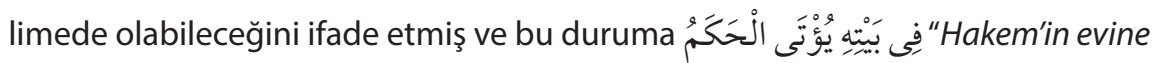

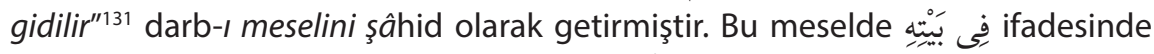
zamirin mercii kendisinden sonra gelen الْحَكَ إن lafzıdır. ${ }^{132}$

İbnu'ş-Şecerî eserinde darb-ı mesellerin yanı sıra sahabe ve tabiin sözlerinden de istişhâdda bulunmuştur. Örneğin, nidânın istiğâse manasına gelebileceğine, inkârcı birisinin Hz. Ömer'i yaralayınca söylediği يا لله ولَلْمسلمين "Ey Allahım Müslümanlara yardım et" sözlerini şâhid olarak getirmiştir. ${ }^{133}$

İbnu'ş-Şecerî nidâda duyurulma kastı olmayabileceğini söylemiş; bu duruma $\mathrm{Hz}$. Ali'nin dünyaya yaptığı nidâyı şâhid olarak getirmiştir. ${ }^{134}$

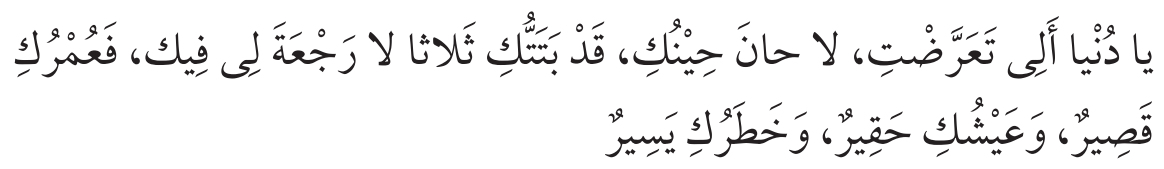

"Ey Dünya! Bana mı kastediyorsun, zaman senin zamanın değil. Üç talakla seni boşadım ve artık benim için sana dönüş yoktur. Senin ömrün kısa, yaşamın hakîr, tehlikelerin ise kolay aşılır."

\section{4. Şiir}

Dille ilgili çalışmalarda hangi şairlerin şiirleriyle istişhâd edileceği meselesi dil âlimleri arasında ihtilaf konusu olmuştur. Fasih Arapçanın kurallarını tespit eden ve lugat hazinesini toplayan dil âlimleri eski dilsel malzemeyi değerlendirip ondan yararlanırken şairleri birtakım tabakalara ayırmışlar ve bu tabakaları ölçü olarak kullanmışlardır. ${ }^{135}$

Bu bağlamda Abdulkâdir el-Bağdâdî (ö. 1093/1682) Hizânetu'l-Edeb adlı eserinde birtakım tasnifler yapmıştır. Bunlar arasında genel olarak kabul gören tasnif ise şu şekildedir: ${ }^{136}$

131 el-Meydânî, Mecma 'u'l-emsâl, II, 72.

132 İbnu'ş-Şecerî, el-Emâlî, III, 115.

133 İbnu'ş-Şecerî, el-Emâlî, l, 420.

134 ỉbnu'ş-Şecerî, el-Emâlî, l, 420.

135 Nihad M. Çetin, Eski Arap Şiiri, (İstanbul: Kapı Yayınları, 2019), 4; Ayrıca bkz. Hüseyin Tural, "Arap Dilinde Şiir ve Hadisle İstişhâd Mes'elesi", Atatürk Üniversitesi Illahiyat Fakültesi Dergisi, 9 (1990): 67-79.

136 Abdulkâdir b. Ömer el-Bağdâdî, Hizânetü'l-edeb ve lübbü lübâbi Lisâni'l-Arab, (Kâhire: yy, 1997), l, 5-6. 
Câhiliyyûn: İmru'u'l-Kays (ö. 540 civarı) ve el-A'şâ (ö. 7/629) gibi İslâmiyetten önce yaşamış şairler bu tabakaya aittir.

Muhadramûn: Lebîd (ö. 41/661), Hassân b. Sâbit (ö. 60/680) gibi hayatlarının bir bölümünü Câhiliye döneminde bir bölümünü de İslâmiyet döneminde yaşamış olan şairlerden oluşan tabakadır.

Mutekaddimûn veya İslâmiyyûn: İslâmi devrin ilk zamanlarında yaşamış şâirlerin oluşturduğu tabakadır. Cerîr (ö.110/728) ve el-Ferazdak (ö.114/732) gibi şâirler bu tabakaya aittir.

Muvelledûn veya muhdesun: Beşşâr b. Burd (167/783) ve Ebû Nuvâs (ö. 198/813) gibi üçüncü tabakadan sonra gelen şairlerdir.

el-Bağdadî'ye (ö. 1093/1682) göre ilk iki tabaka şairlerinin şiirleriyle istişhâdda bulunma konusunda ittifak varken; üçüncü tabakada yer alan şâirlerin şiirleriyle istişhâdda bulunma konusunda ihtilaf olmakla birlikte yaygın olan görüşe göre delil olarak kabul edilmiştir. Dördüncü tabakaya ait şâirlerin şiirleriyle ise bazı hususi sebepler ve istisnalar dışında genel olarak istişhâd uygun görülmemiştir. ${ }^{137}$

Bununla birlikte edebî ilimlerden sarf, nahiv ve lugatte ilk üç tabakadaki şairlerin şiirleriyle istişhâd edilirken, belâgat ilimleri olan meânî, beyân ve bedî' de ise ilk üç tabakadaki şairlerin şiirlerinin yanı sıra muvelledûn (muhdesûn) dönemi şairlerinin, hatta Arap olmayan şairlerin şiirleriyle de istişhâd câiz görülmüştür. ${ }^{138}$ Ibnu'ş-Şecerî de eserinde Arap şiirinden istifâde etmiş, başta sarf ve nahiv olmak üzere belâgat, lugat, edebiyat, arûz gibi ilimlerle ilgili konularda Arap şiirinden istişhâdda bulunmuştur.

İbnu'ş-Şecerîel-Emâlî́sinde tekrarlar ve son meclisteki el-Mutenebbî'ye (ö. 354/965) ait şiirler dışında bin yüz beyitten istişhâdda bulunmuştur. ${ }^{139}$ Ibnu'ş-Şecerî yukarıda zikrettiğimiz cahiliyyûn, muhadrâmûn, mutekaddimûn/islâmiyyûn ve muhdesûn/muvelledûn tabakalarının hepsinden istişhâdda bulunmuştur. Kendisiyle istişhâdın caiz görülmediği muhdesûn/muvelledûn tabakasından Di'bil el-Huzâî (ö. 246/860), Mervân b. Ebî Hafsâ (ö. 182/798), İbnu'l-Mutez (ö. 296/908), Ebû Temmâm (ö. 231/846), el-Buhturî (ö. 284/897), el-Mütenebbî (ö. 354/965) ve İbn Nubâte (ö. 405/1014) gibi şairlerin şiirlerinden istişhâddda bulunmuştur. 
İbnu'ş-Şecerî en çok istişhâdda bulunduğu şairlerin başında muhdesûndan olan el-Mütenebbî (ö. 354/965) gelmektedir. el-Mütenebbî'ye tahsis ettiği son meclisindeki şiirleri dışında, seksen beş yerde kendisinden şiirler zikretmiş ve istişhâdda bulunmuştur. ${ }^{140}$ Örneğin, istifhâmın talep ifade edebileceğini söyleyen ibnu'şŞecerî bu duruma el-Mütenebbî'nin şu beytini şâhid olarak getirmiştir:141

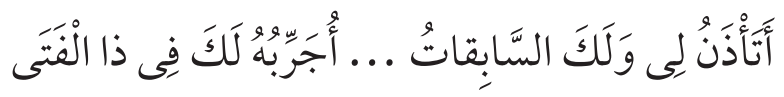

"-Geçmiş iyilikler senin olsun- şu gençte (kılıcı) senin için tecrübe etmeme izin verir

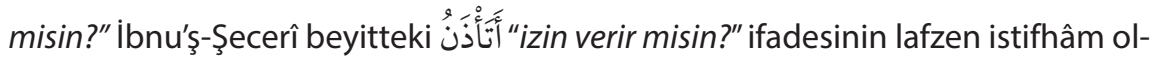
makla birlikte أَذَذَنْ لِي "bana izin ver” anlamında talep ifade ettiğini belirtmiştir.

Ibnu'ş-Şecerî́nin el-Mütenebbî'ye olan ilgisi onu şairin şârihleri arasında zikredilmesini sağlamıştır. Bu bağlamda şairin beyitlerindeki kelimeleri izah ederken başka şairlerin beyitlerinden istişhâdda bulunmuştur. Örneğin,

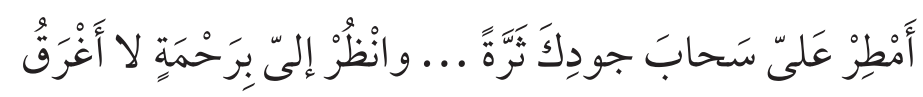

"Cömertliğinin bulutuyla bana çokça yağmur yağdır. Ve rahmetinle bana bak ki boğulmayayım." ibnu'ş-Şecerî buradaki "سَحَ ifadesinin "çok su" manasında olduğunu, çok koşan attan istiâre yapıldığını söylemiş ve şu beyti istişhâd olarak

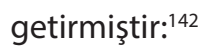

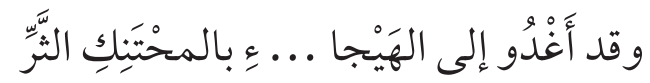

"Savaşa çok tecrübeli atlarla gidiyorum."

İbnu'ş-Şecerî belâgat konularından olan tağlîb konusunu işlerken القََّمَان lafzının güneş ve ay manasına geldiğini söylemiş ve mütekaddimûn/islâmiyyûn dönemi şairlerinden el-Ferezdak'tan (ö. 114/732) şu beyti şâhid getirmiştir:

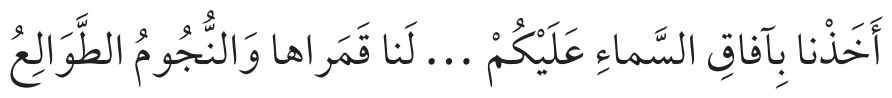

140 ìbnu'ş-Şecerî, el-Emâlî, (muh. mukaddimesi), I, 103.

141 ìbnu'ş-Şecerî, el-Emâlî, I, 327.

142 İbnu'ş-Şecerî, el-Emâlî, I, 122. 
"Size karşı semânın âfâkını tuttuk. Semânın iki kameri ve doğan yıldızlar bizimdir."143 İbnu'ş-Şecerî bu beyitte قَمَكَاهـا lafzıyla zikredilen iki kamerle güneş ve ayın kastedildiğini belirtmiştir. ${ }^{144}$

ibnu'ş-Şecerînin eserindeki beyitlerin sayısına baktığımız zaman bu örnekleri arttırmak mümkün fakat bu kadar örneğin fikir vermesi açısından yeterli olacağını düşünüyoruz. Genel olarak şunu söyleyebiliriz ki, Ibnu'ş-Şecerî her dört tabaka şairlerin şiirlerinden istifade etmiştir. Diğer dilcilere kıyasla muhdesûndan olan şairlerin şiirlerini istişhâd olarak daha çok kullanmıştır.

\section{9. el-Emâlî'de Ele Alınan Konular}

İbnu'ş-Şecerî́nin el-Emâlîs'si seksen dört meclisten oluşmaktadır. Bu meclislerde Arap dilinin hemen hemen bütün alanlarılla ilgili konulara temas edilmiştir. İbnu'ş-Şecerî bazen bir nahiv meselesini ele almış, bazen sarfla ilgili bir konuyu işlemiş, verdiği örnek beyitlerdeki kelimelerin izahını ve irâbını yapmıştır. Bazı meclisleri belâgat konularına ayıran İbnu'ş-Şecerî, bazı meclislerde ise ayet-hadislerin tefsir-şerh ve irâblarını yapmıştır. Kimi zaman arûz ve kâfiyeye değinmiş kimi zaman ise tarihi bilgiler aktarmıştır. Bunun yanı sıra fıkıh ve felsefe gibi alanlarla ilgili bazı bilgiler de zikretmiştir. Özellikle Arap dili alanında temâyüz eden İbnu'ş-Şecerî'nin birçok ilme vakıf olduğunu ve bunları da eserine yansıttığını görmekteyiz.

Ibn Hallikân (ö. 1282/681) el-Emâlî́nin İbnu'ş-Şecerî'nin en geniş ve en faydalı eseri olduğunu ve özellikle Arap edebiyatıyla ilgili birçok fayda içerdiğini söylemiştir. ${ }^{145}$ Yâfi'î'de (ö. 1367/768) el-Emâlî́nin İbnu'ş-Şecerî'nin en geniş ve en faydaIı eser olduğunu söylemiş ve bu eserin Arap edebiyatıyla alakalı beş ilmi intiva ettiğini ifade etmiştir. ${ }^{146}$ Bu beş sanatın ne olduğu bilindiğinden olsa gerek Yâfiî bununla ilgili bilgi vermemiştir. Ancak meşhur Arap edebiyatı âlimi Abdulkâdir el-Bağdâdî (ö. 1093/1682) Ebû Câ‘fer Ahmed b. Yûsuf el-Endelûsî'den naklen

143 Ayrıca İbnu'ş-Şecerî burada güneşle İbrâhim'in (a.s.), ay ile Muhammed'in (a.s.), yıldızlarla da ehli beytin işaret edildiğini aktarmıştır.

144 İbnu'ş-Şecerî̀, el-Emâlî, l, 19.

145 İbn Hallikân, Vefayâtu'I-A'yân, VI, 45.

146 Ebû Muhammed Afifüddîn Abdullâh b. Es'ad b. Alî b. Süleymân el-Yâfiî, Mir'âtü'l-cenân ve 'ibretü'l-yakzân fîma 'rifeti havâdisi'z-zamân, thk. Halil el-Mansûr, (Beyrut: Dâru'I-Kütübi'I-IIImiyye, 1997), III, 211. 
Arap edebiyatıyla ilgili ilimlerin altı olduğunu aktarmıştır. Bunlar lugat, sarf, nahiv, meânî, beyân ve bedîdir. ${ }^{147}$

el-Emâlî́nin de ihtiva ettiği bu konulardan başta sarf, nahiv, lügat ve belâgat olmak üzere diğer bazı konulara burada kısaca temas etmek istiyoruz.

\subsection{Nahiv}

Ibnu'ş-Şecerî́nin meşhur talebelerinden İbnu'l-Enbârî (ö. 1181/577) hocasının kendi çağdaşları arasında nahvi en iyi bilen kişi olduğu söylemiştir. ${ }^{148}$ Bunun yanı sıra İbnu'ş-Şecerî uzun yıllar nahiv dersleri vermiştir. ${ }^{149}$ İbnu'ş-Şecerî'nin nahve dair görüşlerini el-Emâlîsinde görmekteyiz. Bu anlamda İbnu'ş-Şecerî́nin nahve ait görüşleri birçok çalışmaya da konu olmuştur. Bunlardan en önemlilerinden birisi, Abdulmun'im et-Tikrîtî́nin İbnu'ş-Şecerî ve Menhecuhû fi'n-Nahv adlı yüksek lisans (Bağdat Üniversitesi) çalışmasıdır. et-Tikrîtî bu eseri daha sonra aynı isimle 1974 yılında kitap olarak yayımlamıştır. Eser üç bölümden oluşmaktadır. Birinci bölümde, müellifin hayatını, hocalarını, talebelerini ve eserlerini ele almıştır. İkinci bölümde müellifin görüşlerinin Basra ve Kûfe ekollerinin görüşleriyle olan ilişkisine ve müellifin kendine ait olan görüşlerinden bahsetmiştir. Üçüncü bölümde ise müellifin eserdeki metodunu, mensup olduğu dil ekolünü ve etkilediği dilcileri zikretmiştir. et-Tikrîtî sonuç kısmında İbnu'ş-Şecerî́nin nahivde genel olarak Basralı dilcilerle aynı görüşleri paylaştığını, çok az meselede Kûfeli dilcileri desteklediğini aktarmıştır. Bu bağlamda et-Tikrîtî'nin bu çalışmasının İbnu'ş-Şecerî́nin nahve dair görüş ve yöntemini anlamada önemli bir eser olduğunu söyleyebiliriz. Ibnu'ş-Şecerî́nin nahve dair görüşlerini inceleyen diğer bir önemli eser ise Mahmûd Muhammed et-Tanâhî́nin İbnu'ş-Şecerî ve Ârâuhu'n-Nahviyye adlı doktora tezi (Kâhire Üniversitesi, 1978) çalışmasıdır. et-Tanâhî ayrıca el-Emâlî’nin tamamını tahkîk ederek geniş bir mukaddimeyle birlikte 1992 yılında Kâhire'de yayımlamıştır. et-Tanâhî mukaddimeyi üç bölümde ele almıştır. Birinci bölümde müellifin hayatını, ikinci bölümde ise müellifin nahve dair görüşlerini zikretmiştir. et-Tanâhî müellifin bu görüşlerini altmış dört maddede toplamıştır. Ayrıca bu bölümde el-Emâlî́deki irâb olgusundan, hazfden, eserdeki istişhâd metodundan, eserin kaynaklarından, etkilediği dilcilerden, müellifin mensup olduğu dil ekolünden bahsetmiştir. et-Tanâhî de et-Tikrîtî gibi İbnu'ş-Şecerî́nin Basra ekolüne mensup 
olduğunu söylemiştir. Üçüncü bölümde ise emâlî kavramını açıklamış, müellifin eserdeki metodunu zikretmiştir. et-Tanâhî'nin tahkîki ve mukaddimesi Ibnu'ş-Şecerî ve el-Emâlî́si üzerine çalışan araştırmacılar için önemli bir kaynak konumundadır. Zikrettiğimiz bu iki eserde İbnu'ş-Şecerî'nin nahve dair görüşleri ayrıntılı olarak bulunabilir. Burada örnek olması açısından birkaç görüşünü zikretmek istiyoruz: Ibnu'ş-Şecerî ism-i işaretin zamir yerine kullanılabileceğini söylemiştir. ${ }^{150}$ Örneğin,

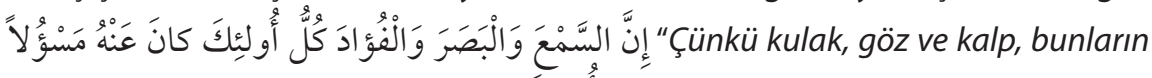

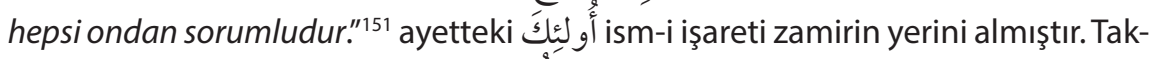
dîri ise şu şekildedir: "Onların hepsi o şeyden sorumludurlar."

Ibnu'ş-Şecerî̀ye göre gayr-i âkil müzekker kelimelerin çoğulunun elif-ta (ات) ile gelmesi caizdir. مَكَ kelimesinin çoğulunun مَكانات şeklinde gelmesi gibi. Bu du-

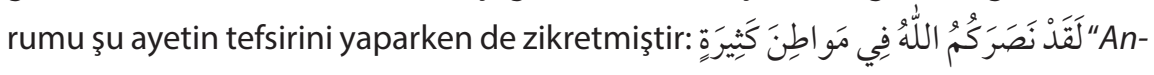

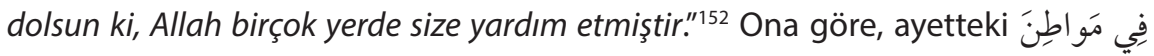

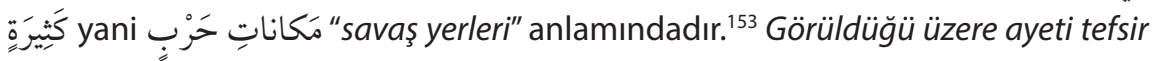
ederken مَ مَو اطِنَ kelimesinin karşılığı olarak مَكانات kelimesini vermiştir.

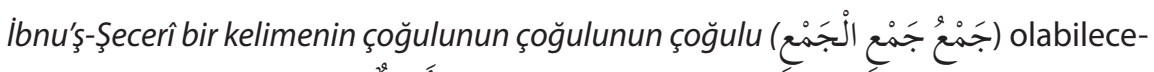
ğini de söylemiş ve buna أَصِيَّ kelimesini örnek vermiştir. Oná göre bu kelimenin

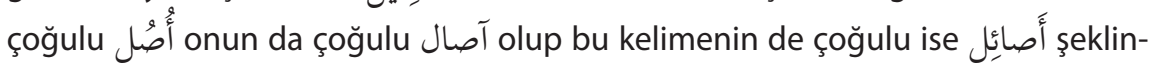
dedir. İbnu'ş-Şecerînnin bu görüşü talebesi Ibnu'l-Haşşâb tarafından eleştirilmiştir. ${ }^{154}$

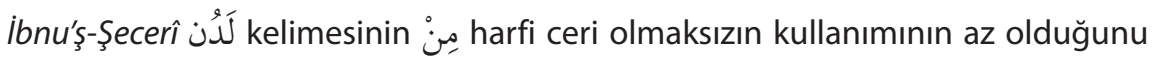
söyleyen İbn Cinnî́yi (ö. 392/1002) eleştirmiştir. Bu duruma şiirlerden örnekler vermiştir. Küseyyir'e (ö. 105/723) ait şu beyit gibi: $:^{155}$

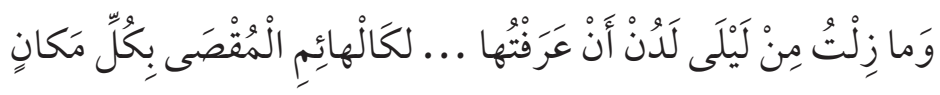

"Leylâyı tanıdığımdan beri (sürüsünden) uzaklaştırılmış her tarafa giden şaşkın (deve) gibiyim."

150 İbnu'ş-Şecerî, el-Emâlî, I, 103.

151 el-i̇srâ 17/36.

152 et-Tevbe 9/25.

153 ìbnu'ş-Şecerî, el-Emâlî, I, 272.

154 İbnu'ş-Şecerî, el-Emâlî, l, 381-382.

155 İbnu'ş-Şecerî, el-Emâlî, l, 338-339. 
İbnu'ş-Şecerî nahivde önemli tartışmalardan birisi olan zunbûriyye meselesinde Sỉbeveyhi'nin (ö. 180/796) görüşünün doğru olduğunu aktarmıştır. Zunbûriyye meselesi Sîbeveyhi (ö. 180/796) ve el-Kisâî (ö. 189/805) arasında gerçekleşen bir münâzaradır. Buna göre, nahiv meselelerini konuşmak için bir araya gelen bu iki

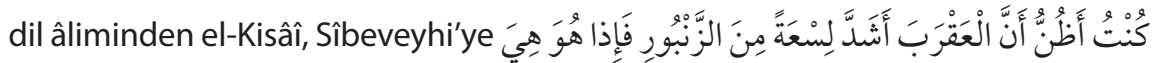
Ben akrep sokmasının eşek arısının sokmasından daha şiddetli olduğunu zannediyordum. Bir de ne olsun o da onun gibiymiş" cümlesinin son kelimesi-

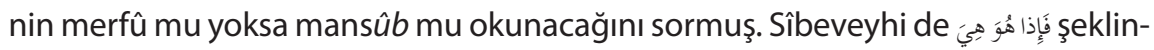
de merfû olarak okunması gerektiğini söylemiştir. el-Kisâi ise bu okumanın hatalı

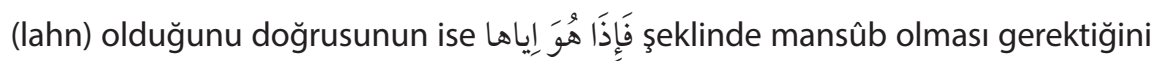
ifade etmiştir. Sîbeveyhi de kendi görüşünde ısrar edince münâzarayı düzenleyen Yahyâ b. Hâlid ihtilafı gidermek için kimin hakem olacağını sormuş, el-Kisâî ise her taraftan gelerek kapıda bekleyen ve Arapçayı en fasih şekilde konuşan bedevî Arapların olduğunu ve onlara bu durumun sorulmasının uygun olacağını belirtmiştir. Kapıda bekleyen ve hakemliklerine müracaat edilen bedeviler arasında yer alan Ebû Fak'as, Ebû Ziyâd, Ebu'l-Cerrâh, Ebû Servân içeriye girmişler, mesele onlara aktarıldığında ise, bunlar el-Kisâî'nin kullanımını doğru bulmuşlardır. ${ }^{156}$ Zunbûriyye meselesinin ve bu meselenin arka planının Basra ve Kûfe ekollerinin görüşlerinin değerlendirilmesi noktasında önemli bir yeri vardır. ${ }^{157}$ iki ekol arasındaki temel meselelerden birisi olan bu konuda İbnu'ş-Şecerî çoğu meselede olduğu gibi Basra ekolünün görüşünü desteklemiştir. Bu mesele bir anlamda İbnu'ş-Şecerî́nin hangi ekole mensup olduğunu da gösteren bir durumdur.

\subsection{Sarf}

el-Emâlî'de geniş bir şekilde ele alınan konulardan birisi de hiç şüphesiz sarf ilmidir. İbnu'ş-Şecerî'nin el-Emâlî'sindeki sarfa dair görüşleri bazı bilimsel çalışmalara da konu olmuştur. Bunlardan birisi de Ahmet Tekin tarafından hazırlanmış olan Ibnu'ş-Şecerî́nin el-Emâlî Adlı Eserinin Sarf Açısından Incelenmesi adlı çalışmadır. Eser giriş ve iki bölümden oluşmaktadır. Giriş kısmında Arap edebiyatında emâlî geleneği üzerinde durulmuş, birinci bölümde İbnu'ş-Şecerî́nin hayatı ve eserle

156 İbnu'ş-Şecerî, el-Emâlî̀, I, 348-349; Ibnu'I-Enbârî, el-Insâffî mesâili'l-hilâf, (el-Mektebetu'I-Asriyye, 2003), II, 576.

157 Bkz., Nevin Karabela, "Zunbûriyye Tartışması ve Arka Planı", EKEV Akademi Dergisi - Sosyal Bilimler, 2 (2001): 257-264. 
ilgili bazı konular işlenmiştir. Çalışmanın temelini teşkil eden ve İbnu'ş-Şecerî'nin sarfa dair görüşlerinin ele alındığı ikinci bölümde ise mîzan-mevzûn, fiiller, te'kîd nunları, mastarlar, ism-i tafdil, sıfat-ı müşebbehe, taaccûb, ism-i mensûb, tekil-ikil-çoğul lafızlar, maksûr-memdûd-menkûs isimler, i‘lâl, ibdâl, idğâm vasl-kat" hemzeleri gibi konular ele alınmıştır.

el-Emâlîde sarfa dair bilgiler seksen dört meclisin tamamına yayılmış bir şekildedir. Müellif bir ayeti, hadisi veya bir şiiri tahlil ederken buralarda geçen kelimelerin sarf yönleriyle ilgili bilgileri aktarmıştır. Bununla birlikte eserdeki sarfla ilgili kuralların nahve dair daha az oluşu o döneme kadar bu kuralların tespitinin yapılmış olmasından kaynaklanmaktadır. Bu açıdan İbnu'ş-Şecerî'nin sarf ilmine dair görüşleri önceki dilcilerin görüşlerinden çok farklı olmayıp genellikle onları pekiştiren ve açıklayan türden görüşlerdir. Nitekim eserdeki sarfa dair bilgilere Sîbeveyhi'nin (ö. 180/796) el-Kitâb'ında, el-Müberred'in (ö. 286/900) el-Muktedab'ında ve İbnu's-Serrâc'ın (ö. 316/929) el-Usûl'ünde görmekteyiz. Fakat İbnu'ş-Şecerî'nin vermiş olduğu bilgilerin daha detaylı ve sistematik olduğu söylenebilir. ${ }^{158}$

İbnu'ş-Şecerî́nin el-Emâlî'sindeki sarfla ilgili görüşleri hakkında fikir vermesi açısından birkaç örnek vermek istiyoruz:

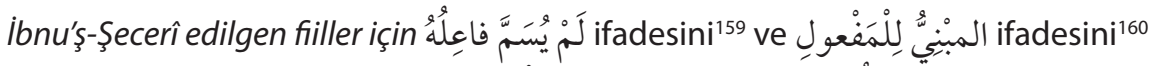

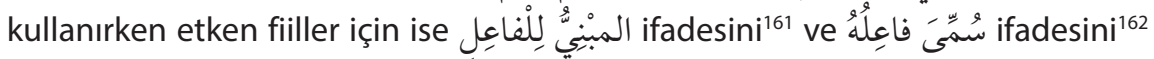
kullanmıştır. Bazı fiillerin ise sürékli edilgen olarak geleceğini söylemiştir. ${ }^{163}$ Örnek olarak ise Şerîf er-Radî'nin (ö. 406/1015) divanından şu beyti vermiştir:

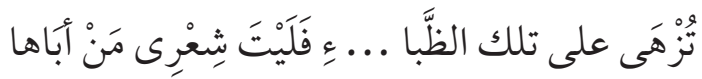

"Şu ceylana karşı kibirleniliyor, keşke babasının kim olduğunu bilseydim."

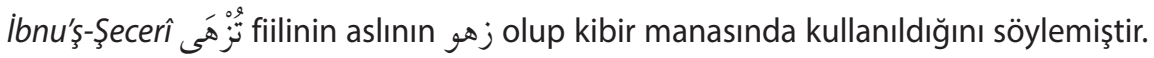

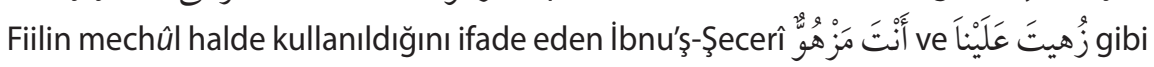

158 Ahmet Tekin, Ibnu'ş-Şecerî́nin el-Emâlî Adlı Eserinin Sarf Açısından Incelenmesi, (Ankara: İlâhiyat Yayınları, 2019), 154.

159 İbnu'ş-Şecerî, el-Emâlî, I, 46; 232.

160 İbnu'ş-Şecerî, el-Emâlî, I, 314.

161 ibnu'ş-Şecerî, el-Emâlî, II, 518.

162 İbnu'ş-Şecerî, el-Emâlî, III, 200.

163 Tekin, Ibnu'ş-Şecerî́nin el-Emâlî Adlı Eserinin Sarf Açısından Incelenmesi, 95. 
ifadelerin "kibirlendin" manasında olduğunu aktarmıştır. Ona göre bu fiil malûm olarak kullanılmaz. ${ }^{164}$

İbnu'ş-Şecerî cümlede fili veya ismi zikredilen mastarların yerine zamir getirmenin daha güzel olduğunu söylemiş ve şu ayeti örnek olarak vermiştir:

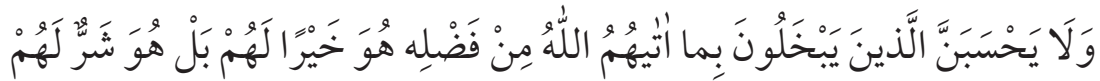

"Allah'ın kendilerine lütfundan verdiği nimetlerde cimrilik edenler, bunun, kendileri için hayırlı olduğunu sanmasınlar. Bilakis, o kendileri için bir şerdir."165 Ayetinde يَبْخَلْونَ failinin mastarı yerine هُوَ zamiri kullanılmıştır. ${ }^{166}$

\subsection{Belâgat}

İbnu'ş-Şecerî́nin eserinde geniş olarak ele aldığı konulardan birisi de belâgattır. Müellif özellikle meânî ilmi üzerinde durmuş ve bazı meclislerini bu konuya ayırmış ${ }^{167}$ bunun yanı sıra beyân ve bedî ilmiyle alakalı bazı sanatları açıklamıştır.

Meâni ilminin altında haber-inşâ meselesini inceleyen İbnu'ş-Şecerî haberin, meânî ilminin en geniş konusu olduğunu söylemiş ve haberi "haber kendisinde doğruluk veya yanlışlık bulunan sözdür" şeklinde tarif etmiştir. ${ }^{168}$ Haberin tarifini yaptıktan sonra haber cümlelerinin ifade ettiği manalar üzerinde durmuştur. Bu anlamda şu durumlarla ilgili örnekler vererek izah etmiştir. Emir ifade eden haber, ${ }^{169}$ ta'ziye (teselli) ve sabır anlamında emir ifade eden haber, ${ }^{170}$ nehiy ifade eden haber, ${ }^{171}$ terbiye amacı güden emir ifade eden haber, ${ }^{172}$ ibâha ifade eden haber, ${ }^{173}$ nedb ifade eden haber, ${ }^{174}$ duâ ifade eden haber, ${ }^{175}$ iğrâ ifade eden

164 İbnu'ş-Şecerî, el-Emâlî, l, 46.

165 Âl-i İmrân 3/180.

166 İbnu'ş-Şecerî, el-Emâlî, II, 37, 385, 507; Tekin, Ibnu'ş-Şecerî́nin el-Emâlî Adlı Eserinin Sarf Açısından incelenmesi, 110.

167 Bkz. İbnu'ş-Şecerî, el-Emâlî, I, 314-435.

168 İbnu'ş-Şecerî, el-Emâlî, I, 390, 424; II, 80.

169 İbnu'ş-Şecerî, el-Emâlî, I, 392.

170 İbnu'ş-Şecerî, el-Emâlî, l, 393.

171 İbnu'ş-Şecerî, el-Emâlî, l, 393.

172 İbnu'ş-Şecerî, el-Emâlî, I, 394.

173 İbnu'ş-Şecerî, el-Emâlî, l, 394.

174 İbnu'ş-Şecerî, el-Emâlî, l, 394.

175 İbnu'ş-Şecerî, el-Emâlî, I, 395; II, 150. Ayrıca bkz. I, 253. 
haber, ${ }^{176}$ vaîd ifade eden haber, ${ }^{177}$ lafzen olumlu cümle olmakla manası olumsuz olan haber. ${ }^{178}$

Müellif diğer belâgatçılardan farklı olarak haber başlığı altında taaccub, kasem ve cezâyı (cevap cümlesi) ${ }^{179}$ da işlemiştir. Ona göre, taaccubda mübâlağa manası olup habere dâhildir. Çünkü bir kimse ما أَحْسَنَ زَيْدِ "Zeyd ne kadar da güzel!" dediği zaman aslında زَيدُ حَسُنَ حِدِّ "Zeyd çok güzel oldu" demek istemiştir. Dolayısıyla ona göre, kastedilen mana itibariyle taaccubun haberin içerisinde olması daha doğrudur. ${ }^{180}$

Kasem bazı belâgatçılar tarafından gayr-i talebî inşâ altında değerlendirilmekle

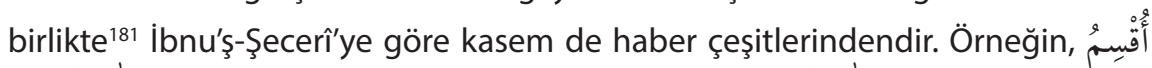
“Allah'a yemin olsun ki gídeceğim" gibi. Müellif kasemin doğrulanabilir veya yanlışlanabilir olacağından dolayı haberin altında değerlendirmiştir.

İbnu'ş-Şecerî́nin inşâ kavramının genel bir tanımını yapmadığını görmekteyiz. Bununla birlikte emir, nehiy ve istifhâmın cümledeki haberî manayı zayıflattığını çünkü haberde doğruluk ve yanlışlık ihtimali söz konusu olduğunu ama bahsi geçen cümle çeşitlerinde böyle bir durumun olmadığına dikkat çekmiştir. ${ }^{182}$ Buradan hareketle İbnu'ş-Şecerî́nin inşâyı, haberin zıddı olarak "Kendisinde doğruluk ve yanIışlık ihtimali olmayan sözdür" şeklinde tanımladığını söyleyebiliriz. Ayrıca inşâda talebî, gayr-i talebî ayrımını da kabul etmediğini anlamaktayız. Zira gayr-i talebî inşâ altında değerlendirilen taaccubu, kasemi habere dâhil etmiştir. Bu anlamda inşâ başlığı altında istifhâm, emir, nehiy, nidâ ve temennîyi ele alarak açıklamıştır.

Müellif meânî ilminde haber-inşâ meselesinin yanı sıra iltifât, ${ }^{183}$ kalb, $^{184}$ tağlîbb $^{185}$ ve hazf gibi konulara temas etmiştir. Bunlardan özellikle hazf konusu üzerinde duran İbnu'ş-Şecerî hazfle ilgili şunları söyler: "ihtisâr (icâz) maksadıyla

176 İbnu'ş-Şecerî, el-Emâlî, I, 396.

177 İbnu'ş-Şecerî, el-Emâlî, I, 399.

178 İbnu'ş-Şecerî, el-Emâlî, I, 399.

179 İbnu'ş-Şecerî, el-Emâlî, l, 390.

180 İbnu'ş-Şecerî, el-Emâlî, I, 390. Ayrıca İbnu'ş-Şecerî 59. ve 60. Meclislerde taaccub meselesini detaylı olarak ele almıştır. Bkz. el-Emâlî, II, 381-422; II, 401.

181 Sadeddîn Mesûd b. Ömer et-Teftâzânî, el-Mutavvel Şerhu Telhîsi'l-miftâh, (Beyrut: yy, 2013), 406.

182 İbnu'ş-Şecerî, el-Emâlî, II, 80.

183 İbnu'ş-Şecerî, el-Emâlî, I, 176.

184 ỉbnu'ş-Şecerî, el-Emâlî, II, 135-136.

185 İbnu'ş-Şecerî, el-Emâlî, I, 19. 
yapılan hazfler Arap sözlerinin en fasih olan şeklidir. Çünkü kelam mahzûfa ihtiyaç duyduğundan ve mana da ancak onunla tamamlandığından mahzûf söylenmiş gibi kabul edilir."186 Bunun yanı sıra otuz dokuzuncu meclisin ortasından elli altıncı meclisin sonuna kadar yaklaşık on yedi mecliste hazf konusunu işleyen İbnu'ş-Şecerî, el-Emâli’sinde en uzun değindiği konulardan birisi hazf olmuştur.

Ibnu'ş-Şecerî belâgatın üç ana bölümünden birisi olan beyân ilminden eserinde birçok farklı meclislerde işlediği teşbîh, istiâre, mecâz ve kinâye sanatlarını örnekler üzerinden açıklamıştır. Bedî́ ilminden ise cinâs, ${ }^{187}$ mübâlağa, ${ }^{188}$ aksu'z-zâhir, ${ }^{189}$ tarsii,, $^{190}$ tıbâk, ${ }^{191}$ te'kîdu'l-medh bimâ yüşbihu'z-zem, ${ }^{192}$ tazmîn, ${ }^{193}$ tevcîh, ${ }^{194}$ istitbâ,'195 mukâbele, ${ }^{196}$ ittisa ${ }^{197}$ gibi sanatları ele almıştır.

\subsection{Lugat}

Ibnu'ş-Şecerînin üzerinde durduğu önemli konulardan birisi de lugattır. İbnu'ş-Şecerî kelimelerin delâletlerine, iştikâkına önem vermiş özellikle şevâhid olarak getirdiği ayet, hadis, şiir ve mesellerde garip olsun veya olmasın bütün lafızların izahını yapmaya çalışmıştır. Ayrıca bu izahları yaparken İbnu's-Sikkît (ö. 244/858), ${ }^{198}$ Ibn Kuteybe (ö. 276/889), ${ }^{199}$ ibn Dureyd (ö. 321/933), ${ }^{200}$ ibn Fâris (ö. 395/1004)201 gibi meşhur dilcilerden nakillerde de bulunmuştur. Bu dilcilerin görüşlerini aktarmakla kalmamış, onlar arasından zayıf bulduğu görüşleri eleştirmiş, doğru bulduğu görüşleri pekiştirmiş, ayrıca dilcilerin görüşleri arasındaki benzerlikleri ve farklılıkları ortaya koymuştur. ${ }^{202}$

186 İbnu'ş-Şecerî, el-Emâlî, II, 123.

187 İbnu'ş-Şecerî, el-Emâlî, l, 87.

188 İbnu'ş-Şecerî, el-Emâlî, I, 280, 284; II, 18.

189 İbnu'ş-Şecerî, el-Emâlî, l, 297-298.

190 İbnu'ş-Şecerî, el-Emâlî, I, 380.

191 İbnu'ş-Şecerî, el-Emâlî, II, 185.

192 İbnu'ş-Şecerî, el-Emâlî, II, 276.

193 i̇bnu'ş-Şecerî, el-Emâlî, II, 433.

194 İbnu'ş-Şecerî, el-Emâlî, III, 72.

195 İbnu'ş-Şecerî, el-Emâlî, III, 136-137, 239.

196 İbnu'ş-Şecerî, el-Emâlî, II, 502; III, 242.

197 İbnu'ş-Şecerî, el-Emâlî, l, 53.

198 İbnu'ş-Şecerî, el-Emâlî, I, 183, 219, 397, 417; II, 170-171, 190, 536, 555.

199 İbnu'ş-Şecerî, el-Emâlî, I, 78, 80-81, 226, 238; II, 462, 570; III, 227.

200 ỉbnu'ş-Şecerî, el-Emâlî, I, 148, 229; II, 488; III,110.

201 İbnu'ş-Şecerî, el-Emâlî, II, 487-488; III, 95, 110.

202 İbnu'ş-Şecerî, el-Emâlî, I, 220; II, 233-234, 488. 
İbnu'ş-Şecerî́nin yapmış olduğu lugavî izahlardan birkaçını örnek olarak vermek istiyoruz:

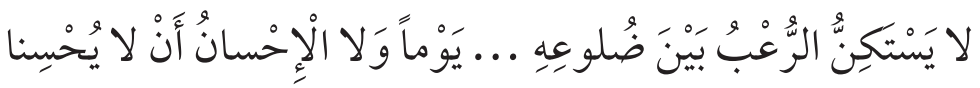

"Korku onun göğsünde bir gün bile kendine yer bulamaz. Iyilik yapmayana da iyilik yapmaz." İbnu'ş-Şecerî, el-Mütenebbî'ye (ö. 354/965) ait bu beyitte geçen الْإِحْسانُ kelimesini şu şekilde açıklar:203 Ihsan kelimesinin sözlükte iki anlamı vardır. Bunlardan birincisi iyilik yapmak ve nimet vermekle aynı anlamda olup kötülük yapmanın zıddıdır. Ayrıca bu kelimenin fiili إلى veya harfi ceriyle müteaddî

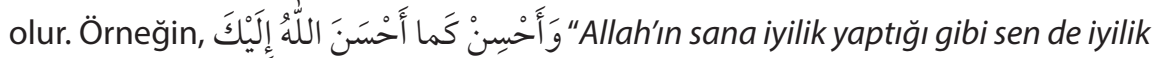
yap." ${ }^{204}$ ihsan kelimesinin sözlükteki ikinci manası ise, bir işi sağlam yapmak anla-

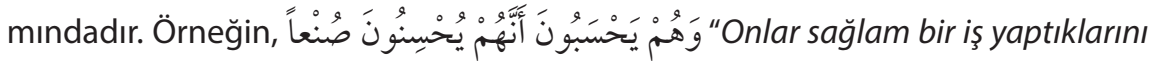
sanıyorlardı."205

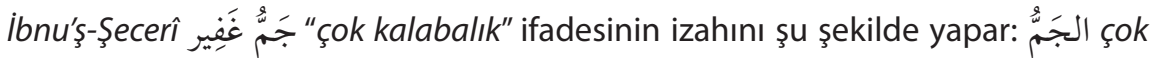
anlamındadır. Örneğin, وَنَفِير

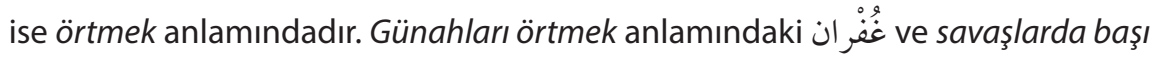

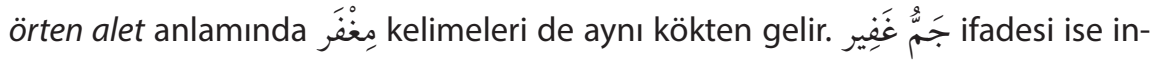
sanların çokça olup yeryüzünü örttüklerinden dolayı bu şekilde kullanılır. ${ }^{207}$

Ibnu'ş-Şecerî lâmul filleri hazfedilmiş kelimelerin izahını yaptığı kırk dokuzuncu

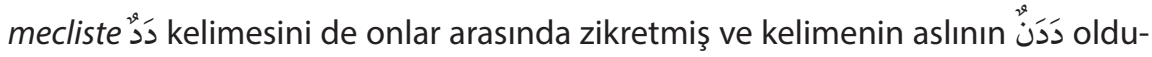
ğunu söylemiştir. Kelimenin oyun ve eğlence anlamında kullanıldığını ifade eden müellif bu duruma şu hadis-i şerifi istişhâd olarak getirmiştir:208

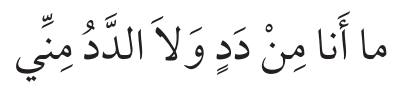

"Ben oyun ve eğlence ehlinden değilim ve oyun-eğlence benim özelliğim değildir."209 Yukarıdaki örneklerde de görüldüğü üzere İbnu'ş-Şecerî kelimelerin sözlük anlamlarını verip izahını yaparken getirdiği şâhidlerle de görüşünü desteklemektedir.

203 ỉbnu'ş-Şecerî, el-Emâlî, III, 192.

204 el-Kasas 28/77.

205 el-Kehf 18/104.

206 el-Fecr 89/20.

207 İbnu'ş-Şecerî, el-Emâlî, III, 20.

208 ibnu'ş-Şecerî, el-Emâlî, II, 232-233.

209 Ebû Ubeyd Kâsım b. Sellâm, Gârîbu'l-Hadîs, (Beyrut: 1976), I, 40; Buhârî, Edebu'l-Müfred, (Beyrut: yy, 1989), 274. 


\subsection{Tefsir-Kıraat}

İonu'ş-Şecerî sarf, nahiv meselelerini ele alırken Kurân-ı Kerîm'den çokça istişhâdda bulunmuştur. İstişhâd olarak getirdiği bu ayetlerin tefsir ve irâbını da yapmıştır. Bunun yanı sıra müellifyedinci, ${ }^{210}$ sekizinci, ${ }^{211}$ dokuzuncu, ${ }_{1}^{212}$ onuncu, ${ }^{213}$ yirmi üçüncü ${ }^{214}$ meclisleri ve diğer meclislerin bazı bölümlerini bir kısım ayetlerin tefsir ve irâbına ayırmıştır. ${ }^{215}$ Ibnu'ş-Şecerî́nin tefsirini yaptığı ayetlerden birkaçı şu şekildedir:

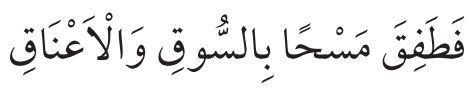

"Boynunu ve bacaklarını kesmeye başladı."216 Ayetteki طَفِ fiili efâl-i mukârebeden olup başladı anlamındadır. timsahla aynı kökten gelir. Çünkü timsahta dişleriyle kılıcın kestiği gibi keser. ${ }^{217}$ İbnu'ş-Şecerî burada مَنْ kelimesine birçok müfessirden farklı anlam verir. Bir başka örnek ise şu ayettir:

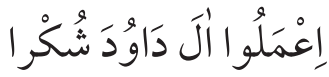

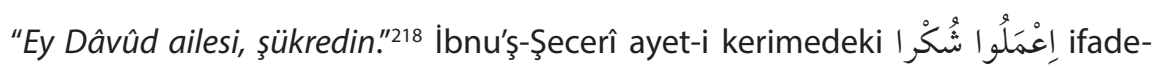
sinin farklı bir kullanım olduğu üzerinde durmuştur. Zirâ Kurân-ı Kerîm'in diğer

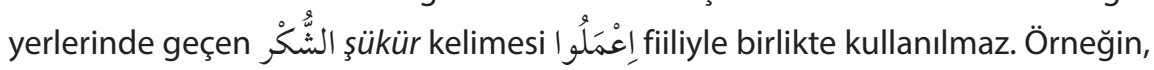
“O'na şükredin. O'na döndürüleceksiniz."219 Ayrıca İbnu'ş-Şe-

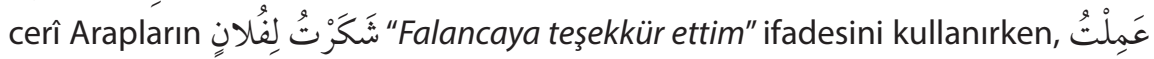
I لَهُ شُكْرُ ifadesini ise kullanmadıklarını söyler. İbnu'ş-Şecerî ayetteki bu kullanımın bazı kişiler tarafından kendisine sorulduğunu söyler ve bu duruma şu şekilde

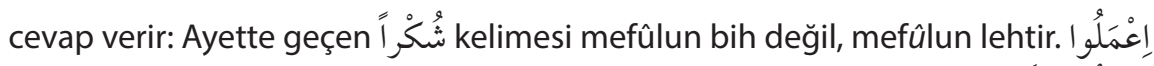

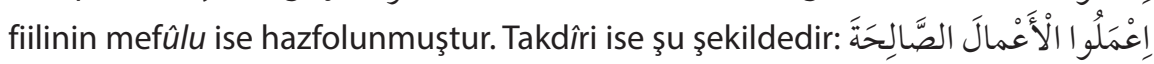

210 İbnu'ş-Şecerî, el-Emâlî, l, 66.

211 ìbnu'ş-Şecerî, el-Emâlî, l, 71.

212 İbnu'ş-Şecerî, el-Emâlî, l, 83.

213 İbnu'ş-Şecerî, el-Emâlî, l, 95.

214 İbnu'ş-Şecerî, el-Emâlî, l, 228.

215 Örnek için bkz.; İbnu'ş-Şecerî, el-Emâlî, I, 220; II, 431; III, 100.

216 Sâd 38/33.

217 İbnu'ş-Şecerî, el-Emâlî, l, 92.

218 Sebe 34/13.

219 el-Ankebût 29/17. 
"Bu nimetlere şükretmek için, sâlih ameller yapın."220 Müellifin tefsirini yaptığı ayetlerden bir diğer örnek şudur:

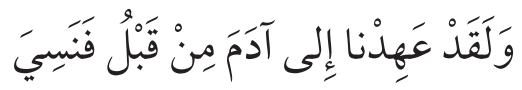

"Andolsun biz, daha önce de Âdem'e ahit vermiştik. Ne var ki o, (ahdi) unuttu."221 İbnu'ş-Şecerî'ye göre ayetteki نَسِيَ "unuttu" ifadesi تَرَكَ "terk etti" anlamındadır. Ben-

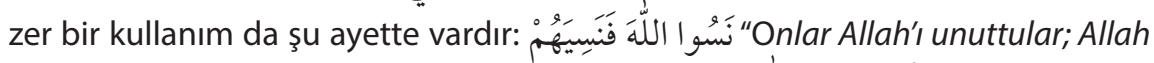

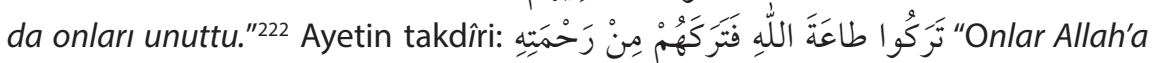
itaati terk ettiler, Allah da onları rahmetinden terk etti (uzaklaştırdı)" şeklindedir. 223

Ibnu'ş-Şecerî yukarıda örneklerini zikretmeye çalıştığımız tefsirlerinin yanı sıra bazı ayetlerin sebebi nüzûluna dair bilgiler de nakletmiştir. Örneğin, Enfâl sûresinin ilk ayetlerine değinirken şu açıklamaları yapmıştır: Bazı sahabenin Bedir Savaşı'na olan ilgisizliğini gören Hz. Peygamber (a.s.) onları teşvik amacıyla ganimet mallarından kendilerine verileceğini söylemiş ancak savaştan sonra ganimet mallarının

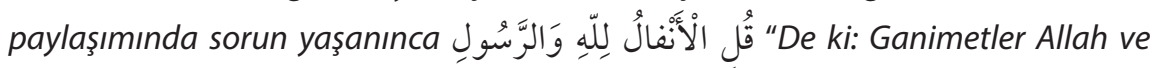
Peygamber'e aittir"224 ayeti nâzil olmuştur. Ancak b́u durum bazı sahabenin ho-

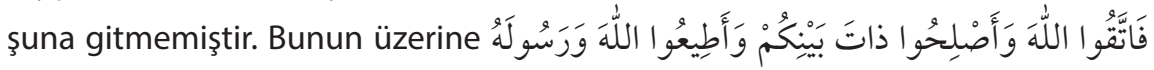
"Allah'tan korkun, aranızı düzeltin, Allah ve Resûlüne itaat edin"225 ayeti nâzil olmuştur. Yani, "Allah ve Rasûlü ganimet konusunda size ne emrediyorsa onu kabul edin" anlamında bir bakıma sahabe uyarılmıştır. 226

Ibnu'ş-Şecerî eserinde kıraatler üzerinde de durmuş, bazı harflerin sıfatlarını açıklamış, ${ }^{227}$ ayetlerin farklı vecihlerinden bahsetmiş ve bunları istişhâd olarak da kullanmıştır. Müellif diğer dilcilerden farklı olarak şâz kıraatleri de istişhâd olarak kullanmıştır. ${ }^{228}$ Ayrıca kıraatlerden bahsederken kendisinin hangi kıraati

220 İbnu'ş-Şecerî, el-Emâlî, II, 126.

221 Tâ-hâ 20/115.

222 et-Tevbe 9/67.

223 İbnu'ş-Şecerî, el-Emâlî, II, 323.

224 el-Enfâl 8/1.

225 el-Enfâl 8/1.

226 İbnu'ş-Şecerî, el-Emâlî, I, 131-132; III, 186.

227 ỉbnu'ş-Şecerî, el-Emâlî, l, 99.

228 İbnu'ş-Şecerî, el-Emâlî, I, 69, 85, 86, 112, 146, 225, 229, 232, 319, 384, 396, 429; II, 42, 46, 86, 172, 187, 189, 222, 237, 304, 306, 368, 419, 431, 522, 526, 550; III, 10, 43, 113, 203, 220. 
kabul ettiğini ve bunun gerekçelerini de izah etmiştir. İbnu'ş-Şecerî kıraatla aynı anlamda harf terimini de kullanmıştır. 229

Ibnu'ş-Şecerî́nin kıraat meselesine yaklaşımıyla ilgili fikir vermesi açısından birkaç örnek zikretmek istiyoruz:

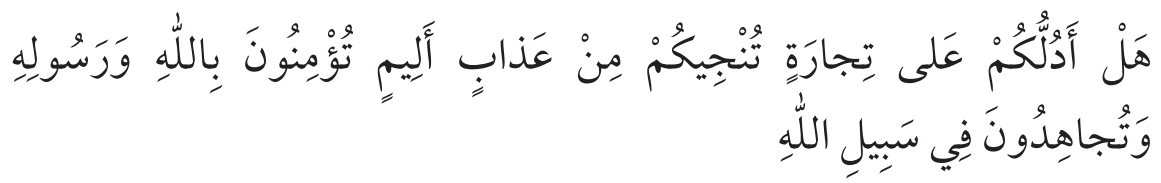

"Sizi acı bir azaptan kurtaracak ticareti size göstereyim mi? Allah'a ve Rasûlü'ne inanın ve Allah yolunda cihad edin."230 İbnu'ş-Şecerî ayet-i kerimedeki تُوَْْنْوَنَ

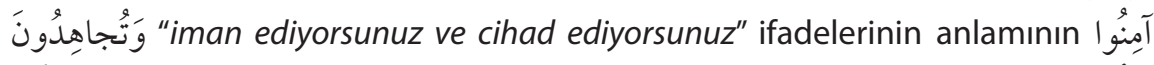

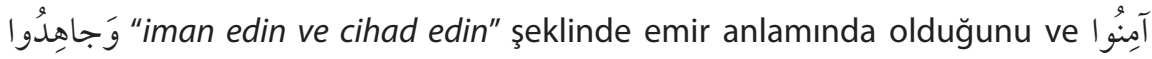
olarak gelen Abdullâh b. Mesûd (ö. 32/652-53) kıraatinin de bunun delili olduğunu söylemiştir. ${ }^{231}$

İbnu'ş-Şecerî kıraat-ı seb’a arasından tercihte de bulunmuştur. Örneğin,

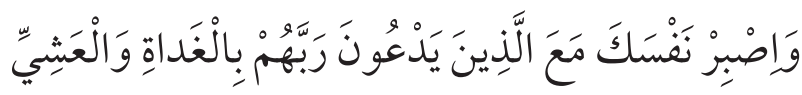

"Sen de sabah akşam Rablerine dua edenlerle birlikte sabret"232 ayetindeki بِالْغَداة lafzını İbn Âmir (ö. 118/736) بَالْغُدْوَة şeklinde okumuştur. İbnu'ş-Şecerî ise İbn Âmir kıraatini zayıf bulmuş ve diğer kıraatin neden daha doğru olduğunu geniş bir şekilde izah etmiştir. 233

Son olarak İbnu'ş-Şecerî'nin şâz kıraatlerden vermiş olduğu bir örnekle bu konuyu noktalamak istiyoruz. Müellif mastar ve ism-i mefûllerin aynı anlama gelebileceği durumu açıklarken şâz kıraatten gelen şu okuyuşu örnek olarak vermiştir: وَنْ يُهِنِ "Allah, kimi alçaltırsa ona saygınlık kazandıracak hiçbir kimse yok-

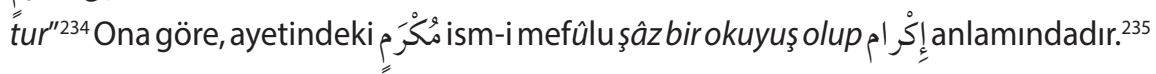

229 İbnu'ş-Şecerî, el-Emâlî, I, 396

230 es-Saff, 61/10-11.

231 İbnu'ş-Şecerî, el-Emâlî, l, 395-396.

232 el-Kehf 18/28.

233 İbnu'ş-Şecerî, el-Emâlî, I, 220-221.

234 el-Hacc 22/18.

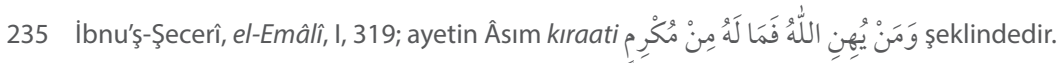




\subsection{Hadis}

İbnu'ş-Şecerî eserinin değişik yerlerinde otuz yedi farklı hadis kullanmıştır. ${ }^{236}$ Bazı meselelere istişhâd olarak kullandığı hadislerin şerh ve irâbını yapmıştır. İbnu'ş-Şecerî ayet ve şiirlere göre ise hadisleri daha az kullanmıştır. Örneğin,

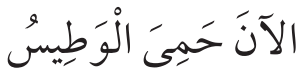

"İşte şimdi tandır tutuştu (savaş kızıştı)."237 İbnu'ş-Şecerî bir beyitte geçen الوَطِِّْْ ke-

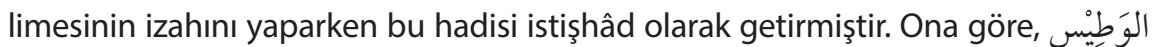
kelimesinin üç anlamı vardır. Birincisi savaş meydanı, ikincisi demir tandır, diğeri ise ekmek yapılan çukur anlamına gelir. Bu hadiste kastedilen ise savaştır. Hz. Peygamber bu sözü Huneyn Gazvesi'nde söylemiş̧tir. Burada savaşın ateşini tandırın ateşine benzetmiş ve bununla savaşın hareketlilik kazandığını ifade etmiştir. ${ }^{238}$

Ibnu'ş-Şecerî إن şart edatının kullanıldığı bazı durumlarda fiilin hazfedileceğini

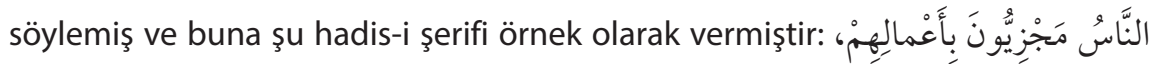

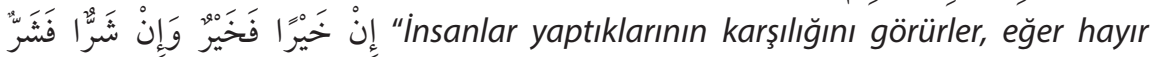
(yaparlarsa) hayırla karşılığını alır, eğer şer (yaparlarsa) şerle karşıığını alırlar." Ha-

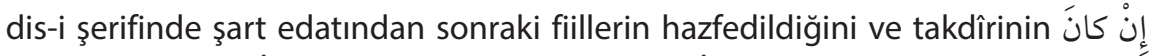

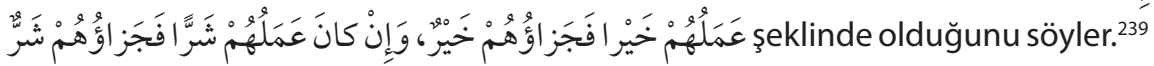
Ibnu'ş-Şecerî yaptığı hadis şerhlerinin yanı sıra bazı hadislerin sebeb-i vurûdunu da açıklamıştır. "S وَجْهَهُ "Sabah akşam Rablerinin rızasını dileyerek O'na dua edenlerle beraber sen de sabret."241 ayeti nâzil olunca Hz. Peygamber (a.s.) şöyle buyurmuştur: الْحَمْدُ لِلَّهِ Ümmetimden, kendileri ile birlikte sabretmekle emrolunduğum kimseler yaratan Allah'a hamd olsun"242

237 Müslim, Kitâbu'l-Cihâd ve's-Siyer, 28.

238 ìbnu'ş-Şecerî, el-Emâlî, III, 215-216.

239 İbnu'ş-Şecerî, el-Emâlî, II, 95.

240 İbnu'ş-Şecerî, el-Emâlî, l, 220-222.

241 el-Kehf 18/28.

242 Ebû Dâvud, Sünen, (Beyrut: Dâru'l-Kitâbi'I-Arabî, tsz.), III, 362; İbnu'ş-Şecerî eserinde hadisin farklı bir rivayetini nakletmiştir. 


\subsection{Fıkıh}

İbnu'ş-Şecerî eserinde Arap dilinin yanı sıra kimi zaman başka konulara da değinmiştir. Bu konulardan birisi de fıkıhtır. Müellif el-Emâlî’de farklı meclislerde at eti yemenin hükmünden, ${ }^{243}$ had cezası gerektiren sözlerden, ${ }^{244}$ alışverişte şahit tutmanın hükmünden ${ }^{245}$ ve talak konusundan ${ }^{246}$ bahsetmiştir. Örneğin, Ibnu'şŞecerî Mâlik b. Enes'in at eti yenilmemesi gerektiği görüşünde olduğunu aktarmıştır. "Atları, katırları ve eşekleri binmeniz ve (gözlere) zinet olsun diye (yarattı)" 247 ayetini bu duruma delil olarak getirmiştir. Deve ile

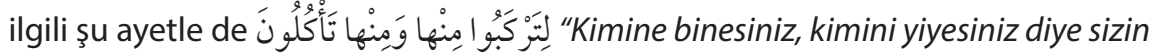
için (hayvanları yarattı)"248 bu görüşü desteklemiştir. ${ }^{249}$

İbnu'ş-Şecerî had cezasını gerektiren sözler ile ilgili de bilgi aktarmıştır. Örneğin, birisine يافُسَّقُ "ey (Fâsık) zinakâr" dendiğinde bu bir haberdir. Çünkü bu nidâ doğruluk ve yanlışlık ifade eder. Ona göre, fukâha bu sözü söyleyen bir iftiracıya had cezasının uygulanması gerektiğini ifade etmişlerdir. ${ }^{250}$

İbnu'ş-Şecerî emrin te'dîb ve irşâd ifade ettiği durumları izah ederken de fıkhî bir meseleye değinmiştir. Ona göre, emrin te'dîb ve irşâd anlamında kullanılması o işin daha sağlam ve düzgün yapılması içindir. ${ }^{251}$ Örneğin,

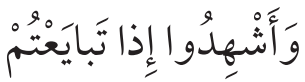

"Alışveriş yaptığınız zaman şahit tutun."252 alışveriş esnasında şahit tutulmadığı durumların alışverişi ifsâd etmeyeceği hususunda ulemânın ittifak ettiğini belirten İbnu'ş-Şecerî buradaki şahit tutulma emrinin ise te'dîb ve irşâd amacıyla söylendiğini ifade etmiştir.

Genel olarak şunu söyleyebiliriz ki, İbnu'ş-Şecerî'nin verdiği fıkhî bilgilerin hepsi ihtilaflı konulardır. Bunlarla ilgili mezheplerin birbirinden farklı görüşleri vardır. Fakat müellif bu ihtilaflara değinmeden bir görüşü zikrederek konuyu geçmiştir.

243 İbnu'ş-Şecerî, el-Emâlî, l, 94.

244 ỉbnu'ş-Şecerî, el-Emâlî, l, 389.

245 İbnu'ş-Şecerî, el-Emâlî, l, 412.

246 İbnu'ş-Şecerî, el-Emâlî, I, 367.

247 en-Nahl 16/8.

248 el-Mümin 40/79.

249 İbnu'ş-Şecerî, el-Emâlî, l, 94.

250 İbnu'ş-Şecerî, el-Emâlî, I, 389.

251 İbnu'ş-Şecerî, el-Emâlî, I, 412.

252 el-Bakara 2/282. 


\subsection{Tarih}

İbnu'ş-Şecerî eserinde bazı tarihi olaylar, ahbâr, ${ }^{253}$ ensâb, ${ }^{254}$ ve eyyâmu'l-arab ${ }^{255}$ ile ilgili bilgiler de aktarmıştır. Lebîd b. Rebî'a'nın (ö. 40 veya 41/660 veya 661) Müslüman olduktan sonra Hz. Ömer'le (r.a.) (ö. 23/644) arasında geçen bir konuşması, ${ }^{256}$ Kays b. Zuheyr ile Rebî' b. Ziyâd arasında zırh pazarlığından kaynaklı bir tartışması, ${ }^{257}$ Halîfe Me'mûn ve Ebû Ali el-Minkarî arasında geçen ve halifenin el-Minkarî́yi azarladığı bir konuşması, ${ }^{258}$ Farsların en büyük melikleri arasında saydığı Enûşirvân ile ilgili bazı tarihi olaylar, ${ }^{259}$ Bekr ve Tağlib kabileleri arasında geçen savaşlar, ${ }^{260}$ Muğire b. Şu'be (ö. 50/670) ve Hind bt. Nu'mân arasında geçen bir diyalog, ${ }^{261}$ Ömer b. Abdulazîz'in (ö. 101/720) hayatından aktarılan bazı olay$\operatorname{lar}^{262}$ bu anlamda eserde ele alınan konulardandır.

İbnu'ş-Şecerî zikrettiğimiz tarihi bilgiler dışında da eserinin değişik yerlerinde bazı nakillerde bulunmuştur. Ancak bunların hepsini burada zikretmek mümkün olmadığından ilgili yerlere işaret ederek ${ }^{263}$ bu konuyu geçmek istiyoruz.

\subsection{Felsefe}

İbnu'ş-Şecerî eserinde meşhur filozoflar Aristoteles (m.ö. 384-322) ve Platon'dan (m.ö. 427-347) da alıntılar yapmıştır. Örneğin, el-Mütenebbî'nin (ö. 354/965) beytini:

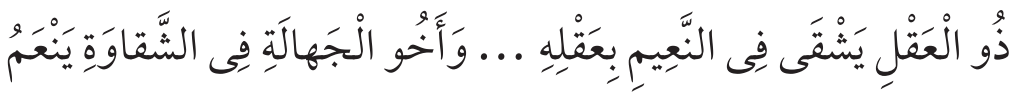

253 Bir şey hakkında naklolunan rivayetler, bilgiler. Bkz. Nihad M. Çetin, "Ahbâr", TDV İslâm Ansiklopedisi, (İstanbul: TDV Yayınları, 1988), I, 486-489.

254 Arap literatüründe kabilelerin soyunu inceleyen ilim dalı için kullanılan bir terim. Mustafa Fayda, “Ensâb", TDV İslâm Ansiklopedisi, (İstanbul: TDV Yayınları, 1995), XI, 244-249.

255 Câhiliye döneminde ve İslâmiyet'in ilk zamanlarında Arap kabileleri arasında meydana gelen savaşlar için kullanılan bir tabir. Mehmet Ali Kapar, "Eyyâmü'l-Arab”, TDV İslâm Ansiklopedisi, (İstanbul: TDV Yayınları, 1995), XII, 14-16.

256 İbnu'ş-Şecerî, el-Emâlî, l, 20.

257 İbnu'ş-Şecerî, el-Emâlî, I, 126.

258 İbnu'ş-Şecerî, el-Emâlî, I, 130.

259 İbnu'ş-Şecerî, el-Emâlî, l, 141-142.

260 İbnu'ş-Şecerî, el-Emâlî, l, 171-172.

261 İbnu'ş-Şecerî, el-Emâlî, II, 450.

262 İbnu'ş-Şecerî, el-Emâlî, II, 64.

263 İbnu'ş-Şecerî, el-Emâlî, I, 23, 26,175, 253, 254; II, 64, 164, 308, 347, 450, 455, 459, 460, 486; III, 135. 
"Bilge kişi aklıyla nimet içinde zorluk çeker, cahil ise zorlukta dahi nimetlenir." Aristoteles'e atfettiği "Akıl kötü yaşamın sebebidir" sözüyle açıklar. ${ }^{264}$ İbnu'l-Mu'tez'in (ö. 296/908) ise bundan ilham alarak şu beyitleri inşâd ettiğini söyler:

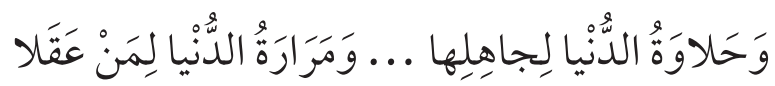

"Dünyanın tatlılığı cahiledir. Dünyanın acılığı ise akıllıya."

Bir başka yerde ise yine el-Mütenebbî'nin (ö. 354/965) beyitleri üzerinden Aristoteles ve Platon'un ruh-beden ilişkisi hakkındaki görüşlerini aktarmıştır:

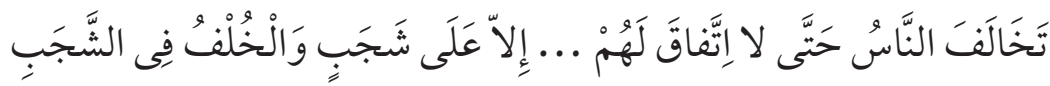

"Insanlar birbiri arasında ihtilafa düştüler ancak ölüm konusunda anlaştılar daha sonra ise onda da ihtilaf ettiler." Şair burada ihtilafın şeklini bir başka beytinde şu şekilde açıklar:

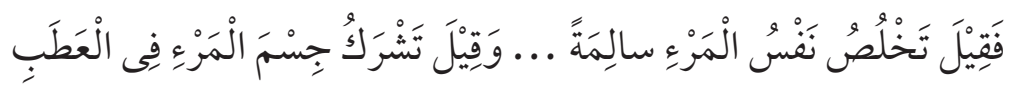

“Denildi ki; kişinin ruhu (bedenden) sağlam bir şekilde çıkar. Ve yine denildi ki; ruh yok olmada (ölümde) kişinin bedenine iştirak eder (onunla birlikte ölür)."

İbnu'ş-Şecerî bu beyitleri verdikten sonra mülhidlerin, ruhun da beden gibi yok olacağını söylediklerini aktarır. Aristoteles ve Platon'un ise bu konuda farklı düşündüklerinin rivayet olunduğunu söyler. Onlardan birisine göre ${ }^{265}$ iyi ruh bedenden çıktıktan sonra yok olmaz. Diğerine göre ise iyi ruh da kötü ruh da yok olmaz. İbnu'ş-Şecerî'ye göre, her kim ki bu görüşü savunursa ruhun dünyada yaptığı hayırlı işlerden dolayı lezzetleneceğini iddia etmiştir. ${ }^{266}$

\section{0. el-Emâlî'nin Kaynakları}

İbnu'ş-Şecerî́nin Arap dili alanında oldukça zengin bir içeriğe sahip olan bu eserini anlayabilmek için onun kaynaklarına dikkatli bakmamız gerekmektedir. Zira

264 İbnu'ş-Şecerî, el-Emâlî, III, 241. Ayrıca felsefe kitaplarının içeriğiyle ilgili bilgisinin olduğuna dair bkz. İbnu'ş-Şecerî, el-Emâlî, III, 240.

265 İbnu'ş-Şecerî burada Aristoteles'i mi yoksa Platon'u mu kastettiğini belirtmemiş olmakla birlikte zikri geçen ilk görüş Platon'a aittir.

266 İbnu'ş-Şecerî, el-Emâlî, III, 261. 
İbnu'ş-Şecerî kendisinden önce yazılmış, dille ilgili eserlerden azami ölçüde istifade etmeye çalışmış, çok değerli bilgiler aktarmıştır.

el-Emâlî́yi önemli kılan yönlerinden birisi günümüze ulaşmayan bazı eserlerden aktarımda bulunmasıdır. Örneğin, Ebu'l-Hasan Ahfeş el-Evsât'ın (ö. 215/830) el-Evsât adlı eserini, Ebû Bekr İbnu'l-Enbârî'nin (ö. 328/940) el-Vâsit adlı eserini bunlar arasında zikredebiliriz. Zirâ bu eserler günümüze ulaşmamıştır. Ayrıca Sîbeveyhi'nin el-Kitâb'ından ve el-Müberred'in el-Muktadab ve el-Kâmil adlı eserlerinden aktardığı bazı bilgilerin bu eserlerin günümüzdeki baskılarında mevcut olmadığı görülmektedir. ${ }^{267}$

İbnu'ş-Şecerî eserinde bir dilciyi eleştirirken onun Arap dilinin bazı temel kitaplarını dikkatli incelemesi gerektiğini söylemiştir. Bunlar arasında ise Halîl b. Ahmed'in (ö. 175/791) Kitâbu'l-Ayn'ını Ibn Dureyd'in (ö. 321/933) el-Cemhere'sini, İbn Fâris'in (ö. 395/1004) el-Mucmel'ini, Ebû İbrâhim el-Farâbî'nin (ö. 350/961) Dîvânu'l-Edeb'ini, el-Cevherî́nin (ö. 400/1009) es-Sıhâh'ını zikretmiştir. ${ }^{268}$ Buradan hareketle şunu diyebiliriz ki, İbnu'ş-Şecerî dille ilgili kendinden önce yazılmış eserlerden haberdar olduğu gibi, onlardan istifade etmekten de geri durmamıştır.

İbnu'ş-Şecerî́nin eserinde ilk olarak aktarımda bulunduğu dilci Ibn Cinnî (ö. 1002/392) ve onun meşhur eseri el-Hasâis'tir. ${ }^{269}$ Bunun yanı sıra, eserinde Ebû Ali el-Fârisî'nin (ö. 377/987) görüşlerini ona nispet etmeden aktardığı yerler olmuştur. ${ }^{270}$

İbnu'ş-Şecerînin kendisinden en çok aktarımda bulunduğu dilci ise Sibbeveyhi'dir. Sîbeveyhi'nin (ö. 180/796) meşhur eseri el-Kitâb'ını on bir yerde ismen zikrederken, Sîbeveyhi'nin adını da yüz elli kez zikretmiştir. Sîbeveyhi'den sonra ismini zikrederek nakilde bulunduğu diğer bir önemli dilci ise el-Ferrâ (ö. 207/822) olup altmış dokuz yerde adını zikretmiştir. ${ }^{271}$ Kırk bir meselede Hâlîl b. Ahmed'den (ö. 791/175) alıntı yapan İbnu'ş-Şecerî, sadece bir yerde onun meşhur eseri Kitâbu'lAyn'a ismen değinmiştir. ${ }^{272}$ Bunların yanı sıra el-Müberred (ö. 286/900) ve esSîrâfî (ö. 368/979) onun en çok istifade ettiği dilciler arasındadır. İbnu'ş-Şecerî kaynaklardan istifade ederken, kimi zaman sadece müellifin adını verirken kimi zaman eserinin adını da zikretmiştir. Bunlar dışında İbnu'ş-Şecerî́nin el-Emâlì'sinin kaynakları arasında şu isimleri de zikredebiliriz:

270 İbnu'ş-Şecerî, el-Emâlî, (muh. mukaddimesi), I, 132.

271 Tekin, Ibnu'ş-Şecerî́nin el-Emâlî Adlı Eserinin Sarf Açııından Incelenmesi, 64-65.

272 İbnu'ş-Şecerî, el-Emâlî, II, 370. 
Sîbeveyhi (ö. 180/796), el-Kisâî (ö. 189/805), Kutrub (ö. 210/825), Ahfeş el-Evsat (ö. 215/830), el-Asmaî (ö. 216/831), el-Cermî (ö. 225/840), İbn Sikkît (ö. 244/858), İbn Keysân (ö. 320/932), ez-Zeccâc (ö. 311/923), Ebû Ali el-Fârisî (ö. 377/987), er-Rummânî (ö. 384/994), İbn Cinnî (ö. 392/1002), el-Kâdî el-Cürcânî (ö. 392/1001-1002), el-Herevî (ö. 401/1011), er-Rebeî (ö. 420/1029), eş-Şerîf el-Murtaza (ö. 436/1044), Mekkî b. EbîTâlib (ö. 437/1045), es-Semânînî (ö. 442/1051), Ebu'l-Alâ el-Maarrî (ö. 449/1057), el-Vâhidî (ö. 468/1076), et-Tebrîzî (ö. 502/1109). ${ }^{273}$

\section{1. el-Emâlî'den İstifade Edenler}

el-Emâlî özellikle sarf, nahiv, belâgat ve lugat ilmiyle alakalı bilgileri ihtiva ettiğinden bu alanlarla ilgilenen kişilerin her zaman dikkatini çekmiştir. Bu anlamda İbnu'ş-Şecerî kendi döneminde olduğu gibi el-Emâlís'syle kendisinden sonraki dönemlerde yaşayan dilciler üzerinde de etkili olmuştur.

İbnu'ş-Şecerî́nin kendi çağdaşları arasında nahvi en iyi bilen kişi olduğu rivayet edilmektedir. ${ }^{274}$ Ayrıca lugat, şiir ve edebiyat alanlarında da döneminin önde gelen isimlerinden birisi olduğu rivayet edilen ${ }^{275}$ Ibnu'ş-Şecerî birçok talebe de yetiştirmiştir. Bunlar arasından kendisini en çok etkilediği en önemli talebesi hiç şüphesiz Ibnu'l-Enbârî'dir. İbnu'ş-Şecerî́nin İbnu'I-Enbârî üzerindeki etkisi eserlerine de yansımıştır. İbnu'I-Enbârî́nin Basra ve Kûfe ekolleri arasındaki ihtilafı konu edinen el-İnsâffî Mesâili'l-Hilâf meşhur eserinde hocası İbnu'ş-Şecerî́nin görüşlerine çokça yer vermiştir. ${ }^{276}$

İbnu'ş-Şecerînnin etkilediği kişilerden birisi de meşhur müfessir el-Kurtûbî'dir (1273/671). el-Kurtubî ayetlerin tefsirini, irâbını yaparken el-Emâlíden çok fazla istifade etmiş̧ir. ${ }^{277}$ Yine ez-Zerkeşî (ö. 794/1392) tefsir alanındaki meşhur eseri el-Burhân'da on dokuz yerde el-Emâlı'den yararlanmıştır. ${ }^{278}$

273 Ayrıntılı bilgi için bkz. İbnu'ş-Şecerî, el-Emâlî, (muh. mukaddimesi), I, 112-155.

274 İbnu'l-Enbârî, Nüzhetu'l-Elibbâ, 300.

275 Yakût el-Hamevî, Mu'cemu'l-udebâ, Vl, 2775.

276 İbnu'l-Enbârî, el-İnsâffîmesâili'l-hilâf, II, 367; Muhammed Hayr el-Hulvânî, el-Hilâfu'n-nahvîbeyne'l-Basriyyîn ve'l-Kûfiyyîn ve Kitâbi'l-Insâf, (Halep: Dâru'I-Kalem, 1971), 131-134.

277 Ebû Abdillâh Muhammed b. Ahmed b. Ebî Bekr b. Ferh el-Kurtubî, el-Câmi 'li-ahkâmi'l-Kur'ân, (Kâhire: Dâru'I-Kutubi'l-Mısriyye, 1964), III, 112; V, 68, 83; VII, 131; XIII, 84; XIV, 347.

278 Bedreddîn ez-Zerkeşî, el-Burhân fî ulûmi'l-Kurân, (Kâhire: Mektebetu Dâru't-Turâs, 1957), IV, 474. Ayrıca bkz. Mustafa Öztürk, "Zerkeşî́nin Kaynakları -el-Burhân fî Ulûmi'l-Kur'ân Üzerine Bir İnceleme-", Çukurova Üniversitesi Illahiyat Fakültesi Dergisi, 2 (2003): 202. 
Ibnu'ş-Şecerî̀den azami ölçüde istifade edenlerden birisi de Arap nahvinin önde gelen isimlerinden olan İbn Hişâm'dır (ö. 761/1360). el-Muğnî adlı eserinde İbn Şecerî'den çokça nakilde bulunan İbn Hişâm zaman zaman eleştiriler de yapmıştır. ${ }^{279}$ Arap dili ve edebiyatına dair geniş bir ansiklopedi mahiyetinde eser olan Hızânetu'l-Edeb'inde Abdulkâdir el-Bağdâdi (ö. 1093/1682) yüz doksan yerde İbnu'ş-Şecerî'nin ismini zikrederek nakilde bulunmuştur. el-Emâlî, el-Bağdâdî'nin en çok istifade ettiği eserlerden birisidir. ${ }^{280}$ Yine meşhur belâgat âlimlerinden birisi olan Bahâuddîn es-Subkî de (ö. 773/1372) Arûsu'I-Efrâh adlı eserinde İbnu'ş-Şecerî'den nakilde bulunmuştur. ${ }^{281}$

Görüldüğü üzere İbnu'ş-Şecerî sarf, nahiv, lügat, belâgat, tefsir gibi farklı alanlardan birçok âlimi etkilemiştir. Yukarıda zikrettiğimiz isimler dışında İbnu'ş-Şecerî́nin etkilediği dilciler arasında şunları zikredebiliriz: el-Ukberî (ö. 616/1219), İbn Ya'îş (ö. 643/1245), el-Muzaffer b. Fadl (ö. 656/1258), İbn 'Usfûr (ö. 669/1270), İbn Mâlik et-Tâî (ö. 672/1274), Radiyuddîn eş-Şâtibî (ö. 684/1285), Ebû Hayyân el-Endelûsî (ö. 745/1344), İbn Ümmi Kâsım el-Muradî (ö. 749/1348), İbn Mektûm (ö. 749/1348), İbn 'Akîl (ö. 769/1367), Bedreddîn el-'Aynî (ö. 855/1451), el-Eşmûnî, Hâlid el-Ezherî (ö. 905/1499), es-Suyûtî (ö. 911/1505), ez-Zebîdî (ö. 1205/1791).

\section{2. el-Emâlî Hakkında Ulemânın Görüşü}

Ibnu'ş-Şecerî́nin eserleri arasında en hacimlisi ve en önemlisi hiç şüphesiz elEmâlî́dir. Müelliften bahseden tabakât kitapları ve diğer eserler de el-Emâlínin önemine değinmeden geçmemişlerdir. İbnu'ş-Şecerî'nin meşhur talebelerinden İbnu'l-Enbârî (ö. 577/1181) eser hakkında şöyle demiştir: "el-Emâlî, Arap diliyle ilgili birçok ilmi kapsayan, çok faydalı nefis bir kitaptır."282

Yâkût el-Hamevî (ö. 626/1229) "el-Emâlî, İbnu'ş-Şecerînin en büyük ve en faydaIı eseridir. Onu seksen dört meclis olarak imlâ ettirmiştir." der.. ${ }^{283}$ İbn Hallikân (ö.

279 Ebû Muhammed Cemâlüddîn Abdullâh b. Yûsuf b. Ahmed b. Abdillâh b. Hişâm el-Ensârî el-Mısłb rî, Muğni'l-lebîb 'an kutubi'l-e 'ârîb, (Dımeşk: Dâru'l-Fikr, 1985), 62, 66, 67, 85, 86, 91, $93,95$.

280 İbnu'ş-Şecerî, el-Emâlî, (muh. mukaddimesi), I, 176-177.

281 Bahâeddîn es-Subkî, Arûsu'I-efrâh fi şserhi Telhîsi'l-Miftâh, (Beyrut: 2003), I, 38, 223, 329, 330, 446, 453, 539; II, 74.

282 İbnu'l-Enbârî, Nüzhetu'l-elibbâ, 300.

283 Yakût el-Hamevî, Mu'cemu'l-udebâ, VI, 2775. 
681/1282) ise "el-Emâli, İbnu'ş-Şecerî'nin en geniş ve en faydalı eseridir. Müellif eseriniseksen dörtmeclis olarakimlâ ettirmiştir. Eser Arap diliyle ilgilibirçokilmi kapsar."284 el-Yemenî (ö. 743/1343) ise eser için şunları söyler:"el-Emâli enfes bir kitaptır. Seksen dört meclisten oluşur ve Arap dilinin garipliklerini içerir. Müellif eserinde başta el-Mütenebbî́nin şiirleri olmak üzere şiirlerin tahlilini ve ayetlerin tefsirini yapar."285 ez-Zehebî (ö. 748/1348) Siyeru A'lâmi'n-Nubelâ adlı eserinde,,286 es-Safedî (ö. 764/1363) el-Vâfí bi'l-Vefeyât adlı eserinde ${ }^{287}$ benzer şekilde eseri övmüşlerdir. Mustafa Sâdık er-Râfi'î (ö. 1937) İbnu'ş-Şecerî́nin kendi döneminde Arap dilinin imamı olup, klasik üslupla emâlî yazan âlimlerin sonuncusu olduğunu söylemiştir. ${ }^{288}$

\section{3. el-Emâlî Üzerine Yapılmış Çalışmalar}

İbnu'ş-Şecerî́nin el-Emâlî'si üzerine ülkemizde yapılan çalışmalar sınırlı sayıdadır. Araştırmamıza başladığımız dönemde müstakil bir çalışma olarak sadece TDV İslam Ansiklopedisi'nde Hüseyin Elmalı tarafından "el-Emâlî" (1995, C. XI, s. 73) adıyla bir madde hazırlanmış olan bu eserle ilgili olarak daha sonra Ahmet Tekin tarafından Ibnu'ş-Şecerî́nin el-Emâlî Adlı Eserinin Sarf Açısından Incelenmesi (IIâhiyat Yayınları2019-) adlı bir çalışma ortaya konmuştur. Bu iki eser dışında ülkemizde yapılmış müstakil bir çalışmaya rastlayamadık. Bu anlamda Arap dilinin önemli eserleri arasında sayılan İbnu'ş-Şecerî́nin el-Emâlî'sinin ülkemizde yeterince incelenmediğini söyleyebiliriz.

Bununla birlikte ülkemiz dışında oldukça ilgi gören İbnu'ş-Şecerî ve el-Emâlîsi üzerine çok sayıda çalışma yapılmıştır. Bunlardan ulaşabildiklerimiz ise şu şekildedir:

- Abdu'l-Mun'im et-Tikrîtî, İbnu'ş-Şecerî ve Menhecuhû fi'n-Nahv, Yüksek Lisans Tezi, Bağdat Üniversitesi. Bu eseri daha sonra aynı isimle 1974 yılında kitap olarak yayımlamıştır.

- Ali Abûd es-Sâhî, İbnu'ş-Şecerî el-Lugavî el-Edîb, Yüksek Lisans Tezi, Kâhire Üniversitesi, 1971.

286 ez-Zehebî, Siyer-i a'lâmi'n-nübelâ, (Kâhire: yy, 2006), XV, 40.

287 es-Safedî, el-Vâfi bi'l-Vefeyât, (Beyrut: yy, 2000), XXVII, 174.

288 Mustafa Sâdık er-Râfi'î, Târîhu âdâbi'l-arabî, (Yy: Dâru'l-Kitâbi'l-Arabî, tsz.), I, 206. 
- Ahmed Hasan Ferhât, Nazarât fî mâ Ehazehû Ibnu'ş-Şecerî 'alâ Mekkî fî Kitâbi Müşkilu I'râbi'I-Kurân, Mecmau'I-Lugatu'l-Arabiyye bi Dımeşk. Bu çalışma üç seri olarak elli birinci sayıdan (1976) itibaren yayımlanmıştır.

- İzzet Ali Abdullâh el-Ğâmidî, Ârâuhu Ibni'ş-Şecerî en-Nahviyye fi'I-Emâli'ş-Şecerî, Yüksek Lisans Tezi, Cidde, 1404.

- Mahmûd Muhammed et-Tanâhî, İbnu'ş-Şecerî ve Ârâuhu'n-Nahviyye, Doktora Tezi, Kâhire Üniversitesi, 1978. et-Tanâhî ayrıca bu eseri tahkik ederek geniş bir mukaddimeyle birlikte 1992 yılında Kâhire'de yayımlamıştır.

- Muhammed İbrâhim Hasan, Ârâuhu Ibni'ş-Şecerî 'inde İbni Hişâm fi'l-Muğnî, Doktora Tezi, Ezher Üniversitesi, 1997. Eser aynı yıl el-Matbaatu'l-İslâmiyye'de basılmıştır.

- Saîd b. Ali b. Abdân el-Ğâmidî, I'tirâdâtu İnni'ş-Şecerî́n-Nahviyye 'ala'nNahviyyîn fi'I-Emâlî, Doktora tezi, Ummu'I-Kurâ Üniversitesi, 1425-1426.

- Rihâb Hasan Abdurraûf, ed-Dersu'd-Delâlî fî Emâli Ibni'ş-Şecerî, Doktora Tezi, İskenderiye Üniversitesi, 2006.

- Âide bt. Şaîd el-Arîbî, el-Hilâfu'n-Nahvî fî Emâli Ilbni'ş-Şecerî, Yüksek Lisans Tezi, Mûte Üniversitesi, 2007.

- Dua Ahmed Hâfız Abdu's-Semî', ed-Dersu'n-Nahvî fí Kitâbi'I-Emâlîli I lbni'ş-Şecerî, Yüksek Lisans Tezi, İskenderiye Üniversitesi, 2007.

- Kâsım İbrâhim Halîl el-Ûsî, Rudûd İbni'ş-Şecerî 'ala'n-Nuhâti fî Mesâili'l-Hilâf Arz ve Tevcîh, Mecelletu Câmiatu Tikrît li'l-Ulûmi'I-İnsâniyye, C. 15, S. 7, 2008.

- Münire Muhammed Fâur, IIlmu'I-Meânî fî Emâli İbni'ş-Şecerî, Mecelletu Mecmau'I-Lugatu'l-Arabiyye bi Dımeşk, C. 86, S. 4, 2011.

- Hâlid b. İbrâhîm en-Nemle, Meâhizu İbni'ş-Şecerî 'alâ Mu 'ribî'I-Kurâni'I-Kerîm, et-Tecdîd, C.16, S. 32, 2012.

- Fayiz Subhî Abdusselâm Turkî, el-Hâlîl b. Ahmed min Hilâli Ârâihi's-Sarfiyye ve'n-Nahviyye fî Emâli Ilbni'ş-Şecerî, el-Mu'temeru'd-Düvelî es-Sâbi' li-Kısmi'nnahv ve's-Sarf ve'n-nahv bi Unvân el-Hâlîl 'Abkariyyu'I-Arabiyye, 2012, 281367.

- Cihâd Muhammed Ramazân el-Hannâvî, Zâhiretu'l-i'râb 'inde Ibni'ş-Şecerî fî kitâbihi'I-Emâlî, Yüksek Lisans Tezi, Gazze İslam Üniversitesi, 2013. 
- Nâdiye Tâha Muhammed Tâha, ed-Dersu'l-Lugâvî fi'l-vav ve'l-ya 'inde Ibni'ş-Şecerî fi'l-Emâlî, Yüksek Lisans Tezi, İskenderiye Üniversitesi, 2016.

- Mahmûd Arâk el-Kureşî, Müsteviyâtu't-Tahlîli'l-Lugavî li'n-Nassi'I-Kurânî (Kırâatun li Kitâb Emâli İbni Şecerî fî Davi'd-Dersi'l-Lisânî el-Hadîs), Mecelletu Lark li'l-Felsefeti ve'I-Lisâniyyeti ve'I-Ulûmi'I-İnsâniyye, C. 1, S. 27, 2017.

- Zeyn Eymen Fethî Abdusselâm, el-Kırâatu'l-Kurâniyye fí Emâli İbni-Şecerî, Mecelletu Kulliyetu'l-Âdâb, Câmiatu'l-İskenderiyye, S. 85, 2017.

- Meryem Sâdık Abbâs el-Umeyrî, eş-Şâhidu'l-Kurânî en-Nahvî fî Hazfi'l-Fi'li 'inde İbni'ş-Şecerî fî Kitâbihi'I-Emâlî, Vâsit li'I-Ulûmi'I-İslâmiyye, C. 14, S. 1, 2018.

- Hüseyin Mübarek İbrâhîm-Muhammed Tâha Mahmûd, Min Mezâhiri't-Te'vîli'n-Nahviyyi'I-Kurâniyyi 'inde I'bni'ş-Şecerî fi'I-Emâli'ş-Şeceriyye, Mecelletu Diyâlî li'l-Buhûsi'l-İnsânîyye, S.77-1, 2018.

- Hâşim Câ'fer el-Musevî-Cabbar İhlîl Zağîr, et-Tevcîhu'n-Nahvî li İbni'ş-Şecerî fî Kutubi'l-Müfessirîn, Mecelletu Külliyetu't-Terbiye, Câmiatu Vâsit, C. 1, S. 37, 2019.

\section{Sonuç}

Imlâ kelimesinin çoğulu olan emâlî, "Bir âlimin belli günlerde başta hadis olmak üzere, Arap dili, tefsir, fıkıh ve diğer ilimlerle ilgili bilgilerini ders halkasındaki öğrencilerine yazdırmasıyla ortaya çıkan bir eser türüdür." İbnu'ş-Şecerî'nin elEmâlîssi de Arap dili alanında yazılmış önemli emâlî türü eserlerdendir. Eserin eksik baskıları olmakla birlikte tamamı Mahmûd Muhammed et-Tanâhî tarafından uzunca bir mukaddime eklenerek üç cilt halinde 1413/1992 yılında Kâhire'de neşredilmiştir.

Seksen dört meclisten oluşan İbnu'ş-Şecerî'nin el-Emâlî'sinde bazı meclislerin başında o meclisin ne zaman yapıldığının tarihi yazılmıştır. Eserde ilk olarak sekizinci meclisin tarihi, son olarak ise otuz üçüncü meclisin tarihi belirtilmiştir. Eserdeki tarih kayıtlarına baktığımız zaman -otuz birinci ve otuz ikinci meclis arasındaki h. 539 yılına dair tarih kaydının daha sonradan eklendiğini düşünürsek- ilk otuz üç meclisin h. 524-536 yılları arasında imlâ edildiğini söylemek mümkündür. Ayrıca son tarih kaydı otuz üçüncü mecliste olup seksen dördüncü meclise kadar olan kısmın tamamlanması müellifin hayatının son anlarına kadar devam ettirilmiş olma olasılığı yüksektir. 
Ibnu'ş-Şecerî meclislerin başında genellikle o meclisi hangi konuya ayıracaksa onu belirtmiş̧ir. Meclislere sarf-nahiv meseleleri, bazı ayetlerin tefsiri, bazı şiirlerin irâb ve mana açısından tahlili ile başlamış, kimi zaman ise kendisine sorulan soruları veya muhtemel soruları cevaplamıştır. İbnu'ş-Şecerî konuları işlerken tekrardan kaçınmaya çalışır, ancak bazen önemine binaen bazı konuları tekrar etmiştir. Müellif anlattığı konuları ayet, hadis, şiir ve mesel örnekleriyle zenginleştirmiştir. İbnu'ş-Şecerînin bu özelliği hemen hemen bütün konularda kendini göstermektedir.

el-Emâlî, çeşitli gramer konuları, meşhur Arap şairlerinin bazı şiirleri, lugat, belâgat, kafiye, arûz, bazı âyetlerin tefsirleri, tarih, ahbâr ve müellifin naklettiği şiirlerde geçen şehirlere dair bilgiler içermektedir. Bazen fasıl veya mesele başlıkları altında mevzû dışına çıkan İbnu'ş-Şecerî kimi zaman kendisine yöneltilen soruları veya muhtemel soruları cevaplandırmakta, kimi zaman ise tarihî ve edebî bilgilere de yer vermekte, meşhur dilcilerin konuyla ilgili görüşlerini aktarmakta, konunun sonunda ise kendi görüşünü ve tercihini belirtmektedir.

Arap dili alanında oldukça zengin bir içeriğe sahip olan bu eserinde müellif kendisinden önce yazıımış dille ilgili eserlerden azami ölçüde istifade etmeye çalışmış, çok değerli bilgiler aktarmıştır. el-Emâlî́yi önemli kılan yönlerinden birisi günümüze ulaşmayan bazı eserlerden aktarımda bulunmasıdır. Örneğin, Ebu'l-Hasan Ahfeş el-Evsat'ın (ö. 215/830) el-Evsat adlı eserini, Ebû Bekr İbnu'l-Enbârî́nin (ö. 328/940) el-Vâsit adlı eserini bunlar arasında zikredebiliriz. Zirâ bu eserler günümüze ulaşmamıştır. Ayrıca Sîbeveyhi'nin el-Kitâb'ından ve el-Müberred'in el-Muktadab ve el-Kâmil adlı eserlerinden aktardığı bazı bilgilerin bu eserlerin günümüzdeki baskılarında mevcut olmadığı görülmektedir. Bunların yanı sıra Hâlîl b. Ahmed (ö. 175/791), İbn Cinnî (ö. 392/1002), Ebû Ali el-Fârisî (ö. 377/987), el-Ferrâ (ö. 207/822) ve es-Sîrâfî (ö. 368/979) gibi dilcilerden istifade etmiştir.

Kendi çağdaşları arasında nahvi en iyi bilen kişi olduğu söylenen ve yetmiş yıl boyunca nahiv dersleri veren İbnu'ş-Şecerî el-Emâli’'siyle gerek kendi döneminde gerekse kendinden sonraki dönemde birçok dilciyi etkilemiştir. Kendisinden en çok istifade edenler arasında başta meşhur talebesi libnu'l-Enbârî́yi (ö. 577/1181) sayabiliriz. Bunun yanı sıra el-Kurtubî (671/1273), ez-Zerkeşî (ö. 794/1392), İbn Hişâm (ö. 761/1360), Abdulkâdir el-Bağdâdi (ö. 1093/1682) el-Emâlî́den en çok istifade eden dilciler arasındadır. 


\section{MîZÂNÜ'L-HAK}

\section{Kaynakça}

el-Afgânî, Saîd. Fîuusûli'n-Nahv. Beyrut: el-Mektebetu'l-İslâmî, 1987.

Ahmed b. Hanbel. Müsned. I-VI Beyrut: yy, 1998.

el-Askerî, Ebû Hilâl. Cemheratu'l-emsâl. I-II Beyrut: Dâru'I-Fikr, tsz.

Aydınlı, Abdullah. "Imlâ". TDV İslâm Ansiklopedisi. XXII, 225-226. İstanbul: TDV Yayınları, 2000.

el-Bağdâdî, Abdulkâdir b. Ömer. Hizânetü'I-edeb ve lübbü lübâbi Lisâni'I-Arab. I-XIII Kâhire: yy, 1997.

el-Buhârî, Muhammed b. İsmâil. el-Câmiu's-Sahîh. I-IX Yy: Dâru Tavki'n-Necât, 1422. . Edebü'l-Müfred. Beyrut: yy, 1989.

el-Cevherî, İsmâil b. Hammâd. Tâcu'I-Iugâ ve Sıhâhu'I-Arabiyye. I-VI, Beyrut: Dâru'I-IIImi li'I-Melâyîn, 1990.

Çetin, Nihad M. Eski Arap Şiiri. İstanbul: Kapı Yayınları, 2019.

. "Ahbâr". TDV İslâm Ansiklopedisi. I, 486-489. İstanbul: TDV Yayınları, 1988.

ed-Dâmin, Hâtim Sâlih. Mâ lem yünşer mine'I-Emâli'ş-Şeceriyye. Beyrut: Müessesetü'r-Risâle, 1984.

Demirayak, Kenan. Arap-İslam Edebiyatı Literatür Bilgisi. İstanbul: Cantaş Yayınları, 2016.

Durmuș, İsmail. "istişhad". TDV İslâm Ansiklopedisi. XXIII, 396. İstanbul: TDV Yayınları, 2001.

. "Mesel". TDV İslâm Ansiklopedisi. XXIX, 295. Ankara: TDV Yayınları, 2004.

Ebû Dâvud. Sünen. I-IV Beyrut: Dâru'l-Kitâbi'I-Arabî, tsz.

Elmalı, Hüseyin. "el-Emâlî". TDV İslâm Ansiklopedisi. XI, 73. İstanbul: TDV Yayınları, 1995.

Fayda, Mustafa. "Ensâb". TDV İslâm Ansiklopedisi. XI, 244-249. İstanbul: TDV Yayınları, 1995.

el-Ferâhîdî, Halîl b. Ahmed. Kitâbu'I-'Ayn. I-VIII Yy: Mektebetu'l-Hilâl, tsz.

el-Hamevî, Yâkût. Mu'cemu'I-udebâ. I-VII Beyrut: yy, 1993.

el-Hulvânî, Muhammed Hayr. el-Hilâfu'n-nahvî beyne'I-Basriyyîn ve'l-Kûfiyyîn ve Kitâbi'l-Insâf. Halep: Dâru'I-Kalem, 1971

el-Isfahânî, er-Râgıb. el-Müfredât fî Garîbi'I-Kur'ân. thk. Safvân Adnân ed-Dâvûdî. Dımeşk-Beyrut: Dân ru'I-Kalem-Dâru'ş-Şâmiyye, 1412.

İbn Hallikân, Ebû'l-Abbâs Şemsuddîn Ahmed b. Muhammed b. İbrâhîm b. Ebî Bekr. Vefayâtu'l-a'yân. I-VII Beyrut: yy, 1994.

İbn Hişâm, Ebû Muhammed Cemâlüddîn Abdullâh b. Yûsuf b. Ahmed b. Abdillâh b. Hişâm el-Ensârî el-Mısrî. Muğni'l-lebîb 'an kutubi'l-e 'ârî̉b. Dımeşk: Dâru'I-Fikr, 1985.

İbn Manzûr, Ebu'I-Fadl Cemâluddîn. Lisânu'I-Arab. I-XV Beyrut: yy, 1993.

İbn Sellâm, Ebû Ubeyd Kâsım. Gârîbu'I-Hadîs. thk. Muhammed Abdulmuîd Hân. I-IV Beyrut: Dâru'IKitâbi'l-Arâbî, 1396.

İbnu'I-Enbârî, Ebû'I-Berekât Kemâluddîn. el-İnsâffî mesâili'I-hilâf. I-II Yy: el-Mektebetu'I-Asriyye, 2003. Nüzhetu'I-Elibbâ. Ürdün: yy, 1985.

İbnu'ş-Şecerî, Ebu's-Sa'âdât Ziyâuddîn Hibetullah b. 'Ali b. Muhammed b. Hamza el-Hâşimî el-'Alevî. Emâlî İbni'ş-Şecerî. I-III Kâhire: yy, 2014.

Kandemir, M. Yaşar. "el-Emâlî". TDV İslâm Ansiklopedisi. XI, 70-72. İstanbul: TDV Yayınları, 1995. 
Kapar, Mehmet Ali. “Eyyâmü'l-Arab". TDV İslâm Ansiklopedisi. XII, 14-16. İstanbul: TDV Yayınları, 1995. Karabela, Nevin. "Zunbûriyye Tartışması ve Arka Planı". EKEV Akademi Dergisi Sosyal Bilimler 2 (2001): 257-264.

Kâtip Çelebî. Keşfu'z-Zunûn. I-VI Bağdat: yy, 1941.

el-Kettânî, Muhammed b. Ca'fer. er-Risâletü'l-Müstetrafe. Beyrut: yy, 1986.

el-Kıftî, Ebu'I-Hasen Cemâluddîn Alî b. Yûsuf b. İbrâhîm b. Abdilvâhid eş-Şeybânî. Inbâhu'r-ruvât. I-IV Beyrut: yy, 1982.

Kızılkaya, Yakup. "Arap Dilinde Kâmin Meseller". Doktora Tezi, Atatürk Üniversitesi, 2014.

el-Kurtubî, Ebû Abdillâh Muhammed b. Ahmed b. Ebî Bekr b. Ferh. el-Câmi ' li-ahkâmi'l-Kur'ân. I-XX Kâhire: Dâru'I-Kutubi'I-Mısriyye, 1964.

el-Meydânî, Ebu'l-Fadl Ahmed b. Muhammed b. Ahmed b. İbrâhîm. Mecma 'u'l-emsâl. thk. Muhammed Muhyiddin Abdulhamîd. I-II Beyrut: Dâru'l-Mârife, tsz.

Müslim b. Haccâc. el-Câmiu's-Sahîh. I-V Beyrut: yy, tsz.

Öztürk, Mustafa. "Zerkeşînin Kaynakları el-Burhân fî Ulûmi'l-Kur'ân Üzerine Bir İnceleme”. Çukurova Üniversitesi Illahiyat Fakültesi Dergisi 2 (2003): 181-211.

er-Râfi'î, Mustafa Sâdık. Târîhu Âdâbi'l-Arabî. I-III, Dâru'I-Kitâbi'l-Arabî, tsz.

es-Safedî, Salâhuddîn Halîl b. İzziddîn Aybeg b. Abdillâh. el-Vâfi bi'I-Vefâyât. I-XXIX Beyrut: yy, 2000.

es-Subkî, Bahâeddîn. Arûsu'I-Efrâh fî Şerhi Telhîsi'I-Miftâh. I-II, Beyrut: yy, 2003.

es-Suyûtî, Celâleddîn. el-Muzhir fi ulûmi'l-lugati ve envâ'ihâ. I-II Beyrut: yy, 1998.

eş-Şevkânî, Ebû Abdillâh Muhammed b. Alî b. Muhammed. Fethu'I-Kadîr. I-VI Beyrut: yy, 1993.

et-Teftâzânî, Sadeddîn Mesûd b. Ömer. el-Mutavvel Şerhu Telhîsu'I-Miftâh. Beyrut: yy, 2013.

et-Tehânevî, Muhammed A'lâ b. Alî b. Muhammed Hâmid. Keşşâfu ıstılâhâti'l-fünûn ve'I-ulûm. I-II Beyrut: Mektebetu'l-Lübnân, 1996.

Tekin, Ahmet. ibnu'ş-Şecerî́nin el-Emâlî Adlı Eserinin Sarf Açısından Incelenmesi. Ankara: Ilâhiyat Yayınları, 2019.

Tural, Hüseyin. "Arap Dilinde Şiir ve Hadisle İstişhâd Mes'elesi." Atatürk Üniversitesi Illahiyat Fakültesi Dergisi, 9 (1990): 67-79.

el-Yâfiî, Ebû Muhammed Afifüddîn Abdullâh b. Es'ad b. Alî b. Süleymân. Mir'âtü'l-cenân ve 'ibretü'l-yakzân fìma 'rifeti havâdisi'z-zamân. thk. Halil el-Mansûr. I-IV Beyrut: Dâru'I-Kutubi'I-IImiyye, 1997.

el-Yemenî, Ebu'I-Mehâsin Tâcuddîn Abdulbâkî b. Abdilmecîd b. Abdillâh. Işâratu't-ta 'yîn fî terâcimi'nnuhât ve'l-lugaviyyîn. thk. Abdulmecîd Diyâb. Riyâd: yy, 1986.

ez-Zebîdî, Abdirrezzâk. Tâcu'l-arûs min cevâhiri'l-Kâmûs. I-XL Yy: Dâru'I-Hidâye, tsz.

ez-Zehebî, Ebû Abdillâh Şemsuddîn Muhammed b. Ahmed b. Osmân. Siyer-i A'lâmi'n-Nübelâ. I-XVIII, Kâhire: 2006.

ez-Zerkeşî, Ebû Abdillâh Bedreddîn. el-Burhân fî ulûmi'I-Kurân. I-IV Kâhire: Mektebetu Dâru't-Turâs, 1957. 
